\title{
Comparison of feeding guild structure and ecomorphology of intertidal fish assemblages from central California and central Chile
}

\author{
Kelly S. Boyle ${ }^{1,2, *}$, Michael H. Horn ${ }^{1}$ \\ ${ }^{1}$ Department of Biological Science, California State University, Fullerton, California 92834-6850, USA \\ ${ }^{2}$ Present address: Department of Zoology, University of Hawaii, 2538 McCarthy Mall, Honolulu, Hawaii 96822, USA
}

\begin{abstract}
The hypothesis of ecological and morphological convergence of the taxonomically distinct intertidal fish assemblages from central California, USA, and central Chile was tested by comparing the feeding guild structures and the morphologies associated with food capture and processing of guild members from each region. We determined the diets of the most abundant intertidal fishes from 3 central California sites by examining gut contents. A matrix of dietary overlap among species within the Californian and Chilean assemblages (diets of Chilean fishes determined in another study) was constructed, and statistically significant guilds were determined using a bootstrapping procedure. Ten morphological features were examined for species in each region, and the relationship between diet and consumer morphology was evaluated. Three feeding guilds, omnivore, microcarnivore, and carnivore, were common to both regions, but a fourth guild, polychaete feeders, was unique to California. Feeding guild structure was not associated with phylogenetic relatedness within either assemblage. An assemblage-wide relationship between diet and morphology was found in each assemblage, but only a few associations between diet and morphology were common to both regions. In both California and Chile, omnivores tended to have longer digestive tracts and closer-set gill rakers, microcarnivores tended to have larger relative mouth heights, and all carnivorous fishes tended to have shorter guts and more widely spaced gill rakers. Overall, interregional morphological patterns were associated with phylogenetic relatedness, rather than with dietary similarities.
\end{abstract}

KEY WORDS: California $\cdot$ Chile $\cdot$ Community convergence $\cdot$ Community divergence $\cdot$ Ecomorphology $\cdot$ Feeding guilds $\cdot$ Fish assemblage structure $\cdot$ Intertidal fishes

Resale or republication not permitted without written consent of the publisher

\section{INTRODUCTION}

The coastal waters of central California, USA (34 to $39^{\circ} \mathrm{N}$ ), and central Chile ( 32 to $37^{\circ} \mathrm{S}$ ) contain taxonomically distinct assemblages of rocky intertidal fishes with no species in common and only 2 co-occurring families (Horn 1999), yet both regions contain highly productive rocky shores bathed by cold eastern boundary currents. Similar ocean temperatures occur off the central Californian and central Chilean coasts (Stepien 1990) because of the cold, southward-flowing California Current and the even colder, northward flowing Humboldt Current off South America (Arroyo et al. 1995). The central California marine region is part of the Oregonian Province and has a climate and fish species richness (Horn 1999, Prochazka et al. 1999) similar to that of the central Chilean coast, which is part of a transition zone between the Peruvian and Chilean biogeographic provinces (Ojeda et al. 2000). The central California intertidal fish assemblage includes fish families with affinities north of the faunal boundary at Point Conception $\left(34.5^{\circ} \mathrm{N}\right)$ (e.g. Cottidae, Pholidae, Stichaeidae), across Point Conception (Embiotocidae), and south of Point Conception (Clinidae) 
(Horn \& Allen 1978, Horn et al. 2006). The central Chile intertidal fish assemblage occurs in a transition zone that includes a mixture of warm-temperate fishes of subtropical origin (e.g. blennioids) and some species of subantarctic origin (e.g. bovichtids) (Mead 1970, Ojeda et al. 2000). These 2 comparable, but spatially distant, intertidal fish faunas differ in taxonomic composition, but occur in habitats that have similar physical features, such as climate, rocky outcrops, and tidal flux, that may exert the same selection pressures. These 2 assemblages thus present an opportunity to test the degree of ecological and morphological similarity between taxonomically distinct fishes in physically similar but geographically separated habitats.

Isolated terrestrial communities (e.g. Mediterranean communities on different continents) have been the subject of far more comparative ecological studies (Karr \& James 1975, Cody et al. 1977, Cody \& Mooney 1978, Holmes \& Recher 1986, Jaksic \& Delibes 1987, Fox 1995, Andersen 1997) than similarly isolated marine communities (Orians \& Paine 1983). The terrestrial communities of California and Chile, for example, possess convergent vegetation types (Mooney et al. 1977, Arroyo et al. 1995) and convergent consumers, especially lizards (Fuentes 1976, Cody et al. 1977). Morphological and ecological convergence has also been examined in freshwater fishes, such as between gymnotiforms of South America and mormyriforms of Africa (Winemiller \& Adite 1997), and among cichlids from Central America, South America, and Africa (Winemiller et al. 1995). Similar studies in the marine environment, however, are lacking. Cross (1982) examined resource partitioning in rocky intertidal fishes of Washington, southern California, and France by surveying their food habits and microhabitat uses, but did not address convergence among these 3 faunas. The intertidal fish species of central Californian and central Chilean coastal waters provide excellent material to test for community convergence in the marine realm.

Intertidal fishes of central California and central Chile are limited to 6 body morphologies and paired fin arrangements as described qualitatively by Horn (1999). Four of these body plans (Fig. 1) are common to the fishes of central California and central Chile despite their disparate phylogenetic affinities, suggesting convergent evolution resulting from the presumed similar selection pressures (Horn 1999): (1) A cylindrical and tapered (terete) body morphology with large, low-set pectoral fins is shared by 3 scorpaeniform families in California and 3 perciform families in Chile. The sculpin (Cottidae) genera Clinocottus and Oligocottus in California and 2 blennioid families (Blenniidae and Tripterygiidae) and the Bovichtidae in Chile have this morphology. (2) A deep and laterally compressed body morphology is represented by different perciform families in central California (Embiotocidae) and Chile (Girellidae). (3) A laterally compressed and shallow-bodied morphology is represented by both

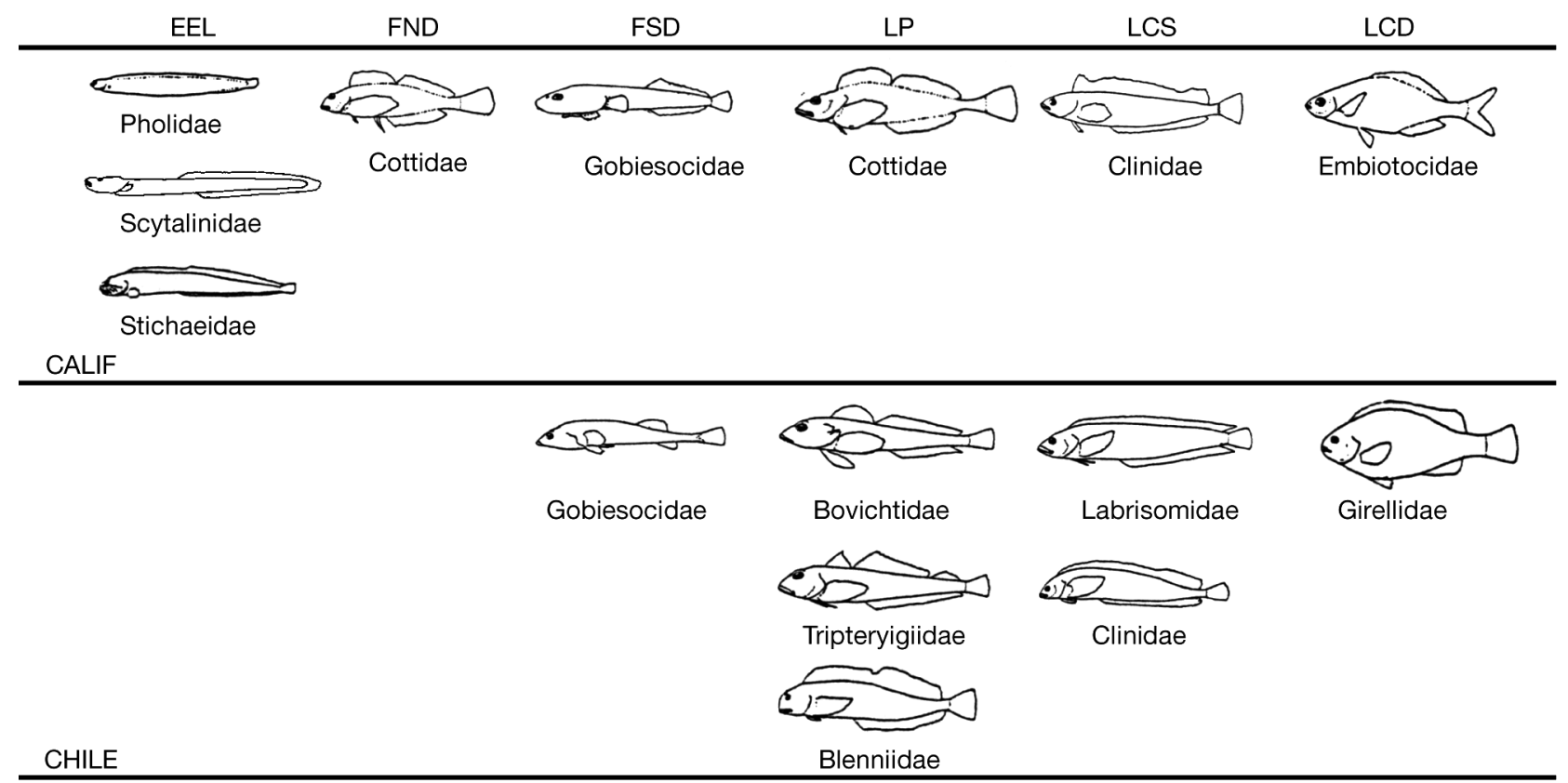

Fig. 1. Outline drawings representing the body plans of each family of fishes from central California and Chile intertidal communities (from Horn 1999). Body plan abbreviations - EEL: elongate, eel-like; FND: flattened without pelvic suction disc; FSD: flattened with pelvic suction disc; TLP: terete with large, low-set pectoral fins; LCS: laterally compressed, shallow-bodied; LCD: laterally compressed, deep bodied 
clinids and labrisomids in Chile, but only clinids in California. (4) A flattened body with a pelvic suction disc is represented by clingfishes (Gobiesocidae) in both regions. Central California fish assemblages contain 2 body morphologies that are not present in central Chile, a dorsoventrally flattened body morphology without a pelvic sucking disc, present in cottids of the genus Artedius, and an elongate (eel-like) body shape. The dorsoventrally flattened body type is represented by cottids of the genus Artedius, and the eel-like shape by 3 zoarcoid families, Stichaeidae (pricklebacks), Pholidae (gunnels), and Scytalinidae (graveldiver). No members of the perciform suborder Zoarcoidei occur in the Chilean intertidal fish assemblage.

The qualitative morphological similarities between these Californian and Chilean assemblages are an impetus for a more quantitative comparison of morphological similarity and tests of their adaptive significance as described by Horn (1999). The degree to which the morphology of the fishes of these 2 assemblages is associated with their feeding ecology could provide insight into which structural traits are adaptive for the niche requirements of the member species. Ecomorphological analyses in general attempt to discern the relationship between an animal's morphology and its pattern of resource use (Motta et al. 1995b). Numerous assemblage-level studies of fish ecomorphology exist (e.g. Grossman 1986, Winemiller 1991, Labropoulou \& Markakis 1998, Piet 1998, Xie et al. 2001), and several investigators have used an ecomorphological approach to test community convergence and divergence (Winemiller 1991, Winemiller et al. 1995, Winemiller \& Adite 1997). Some authors have found no clear evidence of morphological association with ecological functions (Wiens \& Rotenberry 1980, Grossman 1986, Motta 1988, Labropoulou \& Markakis 1998). Indeed, one clear limitation of using ecomorphology to assess convergence is that the investigated morphological characters may strongly influence the observed degree of similarity. Morphological similarities may be correlated with foraging behavior instead of diet (Motta 1988). Nevertheless, a goal of ecomorphological analysis is to determine whether any assemblage-wide correlations exist between morphological features and diet, especially in taxonomically diverse assemblages.

Convergent communities should display quantifiable similarities in resource use. Such similar communities may show differences in species composition and species diversity because of the stochastic variability in ecosystems and the different historical origins but still contain similar functional groups or guilds (Jaksic \& Delibes 1987, Samuels \& Drake 1997). Guilds are groups of species, but not necessarily close taxonomic relatives, that exploit the same resource types (Root 1967). Root's definition of a guild has been used widely by ecologists because it allows researchers to manage the complexity of ecosystems when studying community structure (Jaksic 1981, Hawkins \& MacMahon 1989, Simberloff \& Dayan 1991, Wilson 1999). Determining feeding guild membership a posteriori (when guilds are objectively identified after resource use patterns have been quantified) is a useful way to examine community structure (Jaksic \& Medel 1990, Muñoz \& Ojeda 1997). Resource guilds have been used to compare isolated assemblages from similar environments to determine the degree of concordance in assemblage structure (Holmes \& Recher 1986, Jaksic \& Delibes 1987, Andersen 1997). Ecologically convergent consumer communities are expected to contain analogous guilds that exploit the same types of resources, but comprise unique taxa because of their separate phylogenetic histories.

The underlying mechanisms that cause analogous guilds to arise between unique assemblages have been difficult to determine. One attractive hypothesis is that ecological convergence, and thus the existence of analogous feeding guilds in 2 faunas, may result from convergent evolution between the taxa of different regions. Feeding guild and morphological similarities existing between unrelated members of these regions, however, could also be explained by exaptations, i.e. traits that enhance fitness but did not evolve for their current role (Gould \& Vrba 1982). Thus, feeding guild analogs may contain distantly related taxa, as among geographically separated intertidal fish assemblages, that have homoplastic exaptations related to the type of prey they consume. Overall, morphological similarities between members of feeding guild analogs may be explained by a combination of adaptations, exaptations, and morphological constraints. The robust phylogenetic analysis required to separate adaptations from exaptations (Brooks \& McLennan 1991) has been slow to emerge, including in the Californian and Chilean intertidal fish faunas, which have many subtidal relatives and are represented by a variety of percomorph lineages. Nevertheless, elucidating dietmorphology relationships between unrelated fish assemblages ought to provide insights as to why feeding guild structure exists in fish assemblages.

The first purpose of the present study was to test the hypotheses that: (1) dietary similarity (e.g. guild membership) of fishes within the Californian and Chilean regions is not phylogenetically constrained and (2) dietary overlap exists between the unrelated intertidal fish faunas (guild analogs) of the 2 regions despite their markedly different phylogenetic histories. To test these hypotheses, the feeding guild structures of intertidal fishes from central California and central Chile were compared. This comparison was accomplished by measuring niche overlap within the Californian assem- 
blage and between the Californian and Chilean assemblages using dietary data obtained in the present study for Californian species and from Muñoz \& Ojeda (1997) for the Chilean species. The dietary overlap of fishes within and between assemblages was compared with their phylogenetic relationships based on existing phylogenies. The second purpose of this study was to test the hypotheses that: (1) similarities in the morphology of the feeding apparatus are associated with ecologically (i.e. guild members) rather than phylogenetically related species and (2) morphological similarities exist between ecologically similar species in the unrelated Californian and Chilean faunas despite their unique phylogenetic histories. To test these hypotheses, ecomorphological attributes of the feeding apparatus of Californian and Chilean intertidal fishes were measured and the relationships among morphological similarity, dietary overlap, and phylogenetic relatedness assessed within and between these fish assemblages.

\section{MATERIALS AND METHODS}

Fish collection. Fishes were collected during lowtide periods from 3 rocky intertidal sites on the central Californian coast. Three tidepools at San Simeon Reef $\left(35^{\circ} 40^{\prime} \mathrm{N}, 121^{\circ} 17^{\prime} \mathrm{W}\right)$ were sampled in July 2000 , 5 tidepools at Pescadero Point $\left(37^{\circ} 14^{\prime} \mathrm{N}, 122^{\circ} 25^{\prime} \mathrm{W}\right)$ were sampled in August 2000, and 3 tidepools at Dillon Beach, California $\left(38^{\circ} 17^{\prime}, 122^{\circ} 58^{\prime} \mathrm{W}\right)$, were sampled in July 2001. Tidepools were emptied by bailing with buckets, boulders in the pools were turned over, and fishes were collected by hand and dip nets. This sampling method has been shown to produce results similar to collections made with the ichthyocide rotenone and the anesthetic quinaldine, but with less destructive effects on the tidepool biota (Yoshiyama et al. 1986). Specimens were frozen at $-20^{\circ} \mathrm{C}$ until examined. Dietary analyses were made from 228 individuals belonging to 14 species.

Dietary analyses. Fishes were thawed and measured for standard length $(0.1 \mathrm{~mm})$ and mass $(0.01 \mathrm{~g})$. Some fishes collected from different studies at San Simeon Reef were included in our gut content analysis to augment our sample sizes. Preserved specimens collected in December 1978 (Scytalina cerdale, 1), February 1979 (Micrometrus aurora, 4; S. cerdale, 2; and Xiphister mucosus, 2), March 1980 (Anoplarchus purpurescens, 3 ; S. cerdale, 5 ; X. mucosus, 5 ; and Oligocottus rubellio, 4) and November 1981 ( $M$. aurora, 4) and frozen specimens collected in June 2000 (A. purpurescens, 1 ; Cebidichthys violaceus, 2 ; and X. mucosus, 1), February 2001 (A. purpurescens, 3; Artedius lateralis, 5; and X. mucosus, 1), and June 2001 (A. pur- purescens, 6; C. analis, $1 ;$ X. atropurpureus, 12 ; and X. mucosus, 2) were used in addition to the specimens collected during the fish sampling described above. The stomach (if present) and intestine were cut open, and prey items were flushed into a petri dish, examined under a dissection microscope, and assigned to 1 of the 16 prey categories used by Muñoz \& Ojeda (1997) when appropriate. Use of these prey categories allowed comparison between the 2 faunas and reduced biases stemming from the existence of comparable, but taxonomically different prey items in the 2 regions. Prey items were damp-dried and weighed to the nearest $0.001 \mathrm{~g}$. Diets were quantified using prey biomass rather than number of individual prey items to allow a direct comparison between herbivores and carnivores. Unidentifiable prey items were quantified but not used in the analysis.

Diets for each fish species were expressed as the average relative contribution of each prey type to the total dietary biomass for each fish, rather than summing the biomass of prey types across all individuals. This method reduced the bias of larger fish that contained more total prey biomass than smaller individuals per gut during our analyses. Raw dietary data from the Muñoz \& Ojeda (1997) study were used to express in a similar way the diets of Chilean intertidal fishes. Adequacy of sample size was determined by using cumulative trophic diversity plots as in Grossman (1986) and Muñoz \& Ojeda (1997). Niche breadth of each fish was calculated using Levin's standardized niche breadth, $B_{i}$ (Krebs 1989).

Guild structure. The niche overlap index of Pianka (1973), in which values from 0 to 1 indicate null to complete diet overlap, was used to generate a combined diet overlap matrix (consumers $\times$ diet resources) for the fishes from California and Chile. This matrix was subjected to an unweighted pair-group method with an arithmetic averaging (UPGMA) clustering technique to generate a diet overlap dendrogram. Guilds were identified statistically by using a bootstrapping procedure first proposed by Jaksic \& Medel (1990), in which the resource values (columns) of the dietary overlap matrix are reshuffled randomly 10000 times and overlap values recalculated each time. Lawlor's (1980) Randomization Algorithm 4 was used to generate random overlap values, because it only reassigns non-0 values and thus retains the maximum structure of the dietary matrix (Jaksic \& Medel 1990). Significant overlap values were defined as exceeding the $95 \%$ level of redistribution.

Morphological analysis. Ten specimens of each species from each region were used in the morphological analysis, except for Auchenionchus variolosus (4) and Calliclinus genniguttatus (9). For Californian species, the same frozen specimens collected from 
2000 to 2001 for the dietary analysis were thawed and used in most cases. These fish were supplemented with additional specimens from museums (Table 1). Fish specimens from the central coast of Chile $\left(\sim 33^{\circ} \mathrm{S}\right.$, $71^{\circ} \mathrm{W}$ ) were provided by F. P. Ojeda and students at the Pontificia Universidad Catolica de Chile in Santiago. Additional Chilean specimens were obtained from museum collections (Table 1).

Guided by the definitions of several workers (Gatz 1979, Motta 1988, Kotrschal 1989, Motta et al. 1995a, Labropoulou \& Eleftheriou 1997), we made 12 morphological measurements, hypothesized to be associated with feeding, for each specimen (Table 2). Standard length and gut length were measured to the nearest millimeter using a plastic ruler. Mouth orientation was measured to the nearest $5^{\circ}$ by placing fishes horizontally on a plastic sheet with marked angles (transcribed from a protractor). All other measurements were made to the nearest $0.1 \mathrm{~mm}$ using vernier calipers.

Morphological distances were standardized as relative measures (ratios) to reduce the influence of overall body size and thus to allow for shape comparisons between species (Table 2). Relative morphological measurements have been used by several authors to evaluate relationships between morphological and dietary variables (e.g. Winemiller 1991, Winemiller et al. 1995, Platell \& Potter 2001). Winemiller (1991) cautioned that shape analysis methods, such as truss networks, based on linear measurements of homologous anatomical landmarks and thus genetically constrained, may be undesirable for ecomorphological comparisons of distantly related taxa because these methods may over- look 'general features of form related to ecological function'.

Morphological variation within and between assemblages was examined using principal components analysis (PCA). PCA was performed on the 14 Californian fish species and 13 Chilean fish species separately to characterize the patterns of morphological variation within each assemblage, including those associated with each feeding guild. A third PCA was performed on a combined faunal matrix ( 27 species) to make a direct comparison of the morphologies of the Chilean and Californian fishes.

For each regional PCA, the morphological variation exhibited by each feeding guild was characterized by determining the Euclidean distances of the PC axis scores of guild members for all PC axes with eigenvalues $\geq 1.0$. The matrix of Euclidean distances was used to calculate the distance to the centroid, which provides an estimate of morphological variability relative to the other guilds within the assemblage. The same procedure was used with the combined California-Chile PCA to determine which assemblage was more morphologically variable.

Linear discriminant analysis (LDA), a multivariate classification procedure (Engelman 2000), was used to determine the ability of morphology to predict feeding guild membership and to identify which morphological variables were good predictors of guild assignment. Both automatic forward and backward stepwise LDA were performed to determine which morphological variables were the best predictors of diet. In this process, the morphological variable that contributed most

Table 1. Additional museum specimens used in the morphological analysis (see 'Materials and methods'). Species, number of specimens, location where collected, approximate latitude, collection, and collection number. CSUF: California State University, Fullerton Research Collection; LACM: Los Angeles County Natural History Museum; GCRL: Gulf Coast Research Laboratory; PUC: Pontificia Universidad Catolica de Chile

\begin{tabular}{|llllll|}
\hline \multirow{2}{*}{ Region } & Species & $\mathrm{n}$ & Location & Latitude & Collection \\
\hline California & Anoplarchus purpurescens & 2 & San Simeon, California & $35^{\circ} \mathrm{N}$ & CSUF \\
& Artedius lateralis & 2 & San Simeon, California & $35^{\circ} \mathrm{N}$ & CSUF \\
& Cebidichthys violaceus & 3 & San Simeon, California & $35^{\circ} \mathrm{N}$ & CSUF \\
& Gibbonsia metzi & 2 & San Simeon, California & $35^{\circ} \mathrm{N}$ & CSUF \\
& Micrometrus aurora & 8 & San Simeon, California & $35^{\circ} \mathrm{N}$ & CSUF \\
& Oligocottus rubellio & 4 & San Simeon, California & $35^{\circ} \mathrm{N}$ & CSUF \\
& 2 & San Simeon, California & $35^{\circ} \mathrm{N}$ & LACM, W55-265 \\
& Scytalina cerdale & 5 & San Simeon, California & $35^{\circ} \mathrm{N}$ & CSUF \\
& Xiphister mucosus & 6 & San Simeon, California & $35^{\circ} \mathrm{N}$ & CSUF \\
& Auchenionchus microcirrhis & 1 & Algarroba, Chile & $33^{\circ} \mathrm{S}$ & GCRL, \#12642 \\
& Auchenionchus variolosus & 4 & Con Con, Chile & $33^{\circ} \mathrm{S}$ & PUC, pi\# 0069 \\
& 2 & Antofagasta, Chile & $23^{\circ} \mathrm{S}$ & PUC, pi\# 0042 \\
& Myxodes viridis & 1 & Cocholgue, Chile & $36^{\circ} \mathrm{S}$ & LACM, 55946-2 \\
& 6 & Dichato, Chile & $36^{\circ} \mathrm{S}$ & LACM, 44207-1 \\
& & 1 & Central coast of Chile & $33^{\circ} \mathrm{S}$ & Collected by A. Muñoz, kept at CSUF \\
& Sicyases sanguineus & 7 & Lima, Peru & $12^{\circ} \mathrm{S}$ & GCRL, \#12567 \\
& 3 & Central coast of Chile & $33^{\circ} \mathrm{S}$ & Collected by A. Muñoz, kept at CSUF \\
\hline
\end{tabular}


Table 2. Description and abbreviations of 12 morphological measurements made on 14 Californian and 13 Chilean intertidal fish species and the relative morphological variables derived from these measurements and their abbreviations

\begin{tabular}{|c|c|c|c|c|c|}
\hline Measurements & Description & Abbrev. & Variables used in analyses & Calculated & Abbrev. \\
\hline Standard length & & SL & & & \\
\hline Head length & $\begin{array}{l}\text { Anterior tip of closed jaws to } \\
\text { posterior edge of opercle }\end{array}$ & HL & Relative head length & $\mathrm{HL} / \mathrm{SL}$ & rel HL \\
\hline $\begin{array}{l}\text { Head length } \\
\text { protruded }\end{array}$ & $\begin{array}{l}\text { Anterior tip of jaw protruded to } \\
\text { posterior edge of opercle }\end{array}$ & HLP & Relative head length protruded & HLP/HL & rel HLP \\
\hline Head width & Maximum width of head & HW & Relative head width & $\mathrm{HW} / \mathrm{SL}$ & rel HW \\
\hline Head depth & Maximum depth of head & HD & Relative head depth & $\mathrm{HD} / \mathrm{SL}$ & rel HD \\
\hline Mouth width & $\begin{array}{l}\text { Maximum width of the gape } \\
\text { with the mouth fully open }\end{array}$ & MW & Relative mouth width & MW/HW & rel MW \\
\hline Mouth height & $\begin{array}{l}\text { Maximum height of the gape } \\
\text { with the mouth fully open }\end{array}$ & $\mathrm{MH}$ & Relative mouth height & $\mathrm{MH} / \mathrm{HD}$ & rel $\mathrm{MH}$ \\
\hline Mouth orientation & $\begin{array}{l}\text { Angle from horizontal of the } \\
\text { imaginary plane perpendicular } \\
\text { to the longitudinal body axis and } \\
\text { tangential to both jaws open }\end{array}$ & $\mathrm{MO}$ & Mouth orientation & $\mathrm{MO}$ & $\mathrm{MO}$ \\
\hline Eye diameter & $\begin{array}{l}\text { Diameter of fleshy orbits along } \\
\text { an anterior-posterior axis }\end{array}$ & ED & Relative eye diameter & $\mathrm{ED} / \mathrm{HL}$ & rel ED \\
\hline Gill raker number & $\begin{array}{l}\text { Number of anterior rakers on } \\
\text { both limbs of the first gill arch }\end{array}$ & GN & Gill raker density & GN/GA & GN/GA \\
\hline Gill arch length & $\begin{array}{l}\text { Straight line lengths of the upper } \\
\text { and lower limbs of the first gill arch }\end{array}$ & GA & & & \\
\hline Gut length & $\begin{array}{l}\text { Length from the posterior end } \\
\text { of the esophagus to the anus }\end{array}$ & GL & Relative gut length & GL/SL & rel GL \\
\hline
\end{tabular}

to the separation of trophic guilds was added at each step (forward stepping) and the morphological variable that contributed least to guild separation was removed at each step (backward stepping). Jackknife classification, in which the classifications are computed with all cases (species) except the case being classified, was performed to provide a more conservative estimate of the correct classification rate. In addition to using feeding guilds as classification groups, we used LDA to determine the ability of morphology to predict which species were omnivorous or carnivorous.

Relationships between relative morphological features and consumption of specific kinds of prey were examined by performing linear regressions on all combinations of morphological traits with dietary items using the 10 identified prey categories common to both regions. Separate linear regressions were performed for each assemblage in which the proportion of each prey type was regressed against each relative morphological feature. Multiple comparisons $(k=10)$ of each morphological variable versus the 10 prey categories were corrected using the sequential-Bonferroni method (Rice 1989).

The relationships of dietary overlap versus morphological similarity, dietary overlap versus phylogenetic re- latedness, and morphological similarity versus phylogenetic relatedness were evaluated within each assemblage and between assemblages. Matrices of morphological similarity within each assemblage were calculated using Euclidean distances of all morphological variables and also with the subset of morphological variables determined from the LDA (in which guild was a classification group) for each region. The subset of LDA-determined morphological variables was used to measure the morphological similarity of features that were found to be predictors of feeding guild membership. Matrices of morphological similarity of the combined assemblages were calculated using all morphological variables and also using a combination of morphological variables that were determined from the 2 LDA models of each region. UPGMA dendrograms of morphological (Euclidean) distance were used to provide a visual representation of morphological similarity. Within- and between-assemblage overlap matrices of diet and morphological and phylogenetic distances were compared with Mantel-type and permutation tests (999 permutations) using the RELATE routine in PRIMER Ver. 5 (Clarke \& Warwick 2001). Correlations ( $\rho$ ) between matrices in the RELATE routine were calculated using the Spearman rank correlation method. The phylo- 
genetic hypothesis of relationships of the 2 faunas, although largely untested, was used to provide phylogenetic distances (Fig. 2). The relationships of the blennioids are based on Stepien et al. (1997), and those of the stichaeids follow Stoddard (1985). The zoarcoid families of Nelson (1994) are presented as an unresolved monophyletic group, but other putatively perciform, and scorpaeniform, families are presented as an unresolved polytomy. Multiple table-wide comparisons of the RELATE tests were corrected using the sequentialBonferroni method (Rice 1989).

\section{RESULTS}

\section{Dietary analysis and feeding guild structure}

A total of 228 specimens belonging to 14 fish species from central California were dissected in this study (Table 3), and 172 individuals contained prey items in their guts (Tables 4 \& 5). The families Stichaeidae and Cottidae were represented by the most species at the 3 intertidal sites. Members of the families Pholidae, Scytalinidae, Clinidae, Gobiesocidae, and Embiotocidae were also sampled.

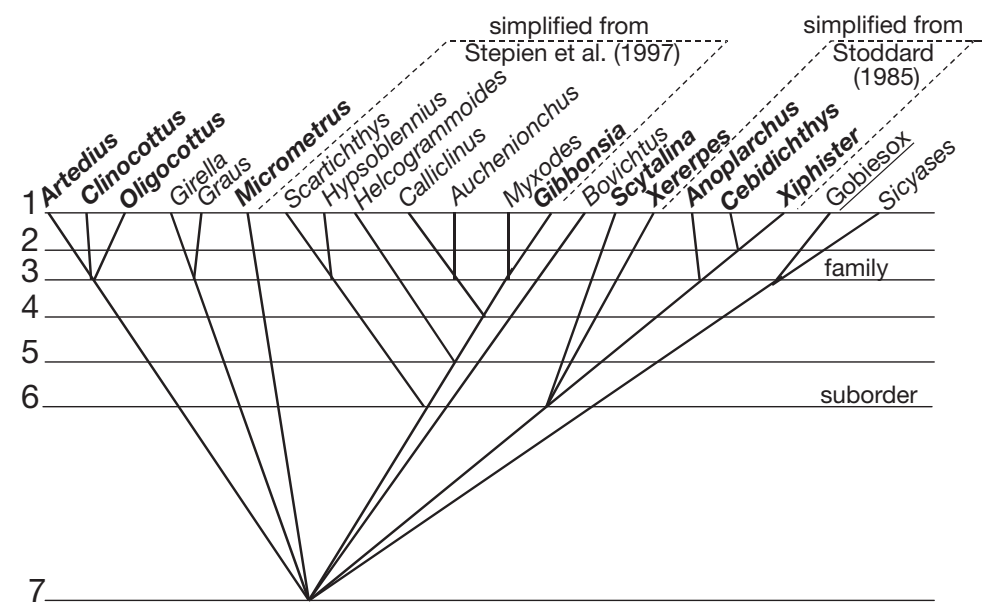

Fig. 2. A condensed phylogeny of the genera represented in the intertidal fish faunas of California (bold), Chile (plain type), and both (underlined). Phylogenetic distances 1-7 were coded at each node (congeners given a distance of 1) to determine the relationship between dietary similarity, morphological similarity, and phylogenetic distance

Three species, Embiotoca lateralis (Embiotocidae), Oligocottus maculosus (Cottidae), and Liparis florae (Liparidae), were collected in low abundance $(<1 \%$ frequency) and were not included in the analysis. Seventeen prey categories were used to describe the

Table 3. Numbers of individuals and sizes of each of the 14 species from San Simeon, Pescadero Point, and Dillon Beach, California, that were dissected for dietary analysis

\begin{tabular}{|c|c|c|c|c|c|c|c|}
\hline \multirow{2}{*}{$\begin{array}{l}\text { Family } \\
\text { Species }\end{array}$} & \multirow[t]{2}{*}{$\mathrm{n}$} & \multicolumn{3}{|c|}{ - Standard length $(\mathrm{mm})$} & \multirow[b]{2}{*}{ Mean } & \multirow{2}{*}{$\begin{array}{l}\text { Neight }(g) \\
\pm \text { SD }\end{array}$} & \multirow[b]{2}{*}{ Range } \\
\hline & & Mean & $\pm \mathrm{SD}$ & Range & & & \\
\hline \multicolumn{8}{|l|}{ Stichaeidae } \\
\hline Xiphister atropurpureus & 18 & 102 & 36 & $67-179$ & 5.46 & 6.62 & $1.1-22.9$ \\
\hline Cebidichthys violaceus & 12 & 88 & 43 & $28-165$ & 7.88 & 10.6 & $0.1-30.0$ \\
\hline Anoplarchus purpurescens & 14 & 67 & 19 & $28-90$ & 2.14 & 1.37 & $0.2-5.0$ \\
\hline Xiphister mucosus & 12 & 118 & 29 & $73-154$ & 7.8 & 5.53 & $1.3-18.3$ \\
\hline \multicolumn{8}{|l|}{ Pholidae } \\
\hline Xererpes fucorum & 13 & 92 & 33 & $41-148$ & 3.7 & 3.38 & $0.3-10.3$ \\
\hline \multicolumn{8}{|l|}{ Scytalinidae } \\
\hline Scytalina cerdale & 19 & 68 & 14 & $46-93$ & 0.78 & 0.51 & $0-1.8$ \\
\hline \multicolumn{8}{|l|}{ Gobiesocidae } \\
\hline Gobiesox maeandricus & 36 & 41 & 12 & $28-67$ & 2.13 & 2.14 & $0.4-7.7$ \\
\hline \multicolumn{8}{|l|}{ Embiotocidae } \\
\hline Micrometrus aurora & 12 & 57 & 18 & $35-90$ & 5.14 & 4.23 & $1.0-15.7$ \\
\hline \multicolumn{8}{|l|}{ Clinidae } \\
\hline Gibbonsia montereyensis & 18 & 81 & 10 & $50-94$ & 7.18 & 2.31 & $1.4-11.4$ \\
\hline Gibbonsia metzi & 9 & 127 & 33 & $78-172$ & 31.7 & 25.2 & $5.0-76.2$ \\
\hline \multicolumn{8}{|l|}{ Cottidae } \\
\hline Oligocottus snyderi & 22 & 54 & 15 & $20-72$ & 4.81 & 2.94 & $0.2-9.0$ \\
\hline Clinocottus analis & 26 & 55 & 15 & $31-96$ & 5.24 & 5.68 & $0.7-25.5$ \\
\hline Artedius lateralis & 10 & 79 & 9 & $64-92$ & 11.9 & 4.65 & $5.6-18.5$ \\
\hline Oligocottus rubellio & 7 & 55 & 7 & $40-61$ & 4.82 & 1.50 & $1.7-6.3$ \\
\hline Total & 228 & & & & & & \\
\hline
\end{tabular}


Table 4. Consumer $\times$ prey resource matrix of intertidal fishes from central Chile (from Muñoz \& Ojeda, 1997). Values are percentages of gravimetric diet contribution of each prey category. Levin's standardized niche breadth values $\left(B_{i}\right.$, Krebs 1989) shown

\begin{tabular}{|c|c|c|c|c|c|c|c|c|c|c|c|c|c|}
\hline & 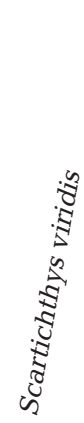 & 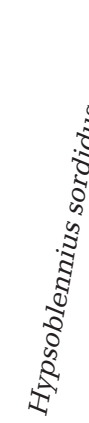 & 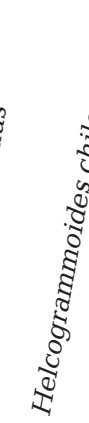 & 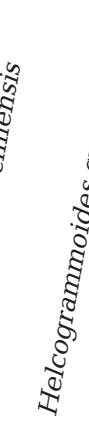 & 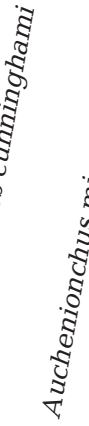 & 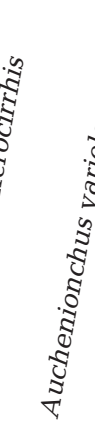 & 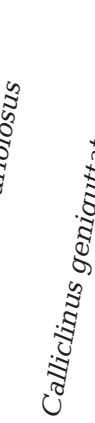 & 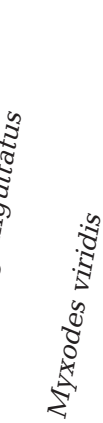 & 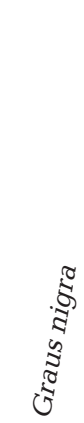 & 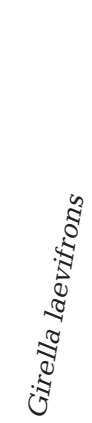 & 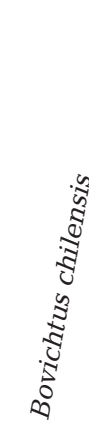 & 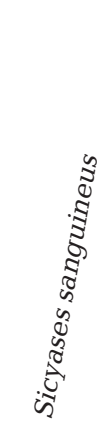 & 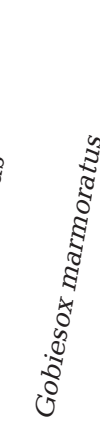 \\
\hline No. fishes examined & 115 & 20 & 97 & 38 & 63 & 27 & 47 & 24 & 72 & 81 & 46 & 20 & 10 \\
\hline No. with gut content & 108 & 19 & 94 & 38 & 56 & 26 & 46 & 24 & 66 & 79 & 42 & 18 & 8 \\
\hline Macroalgae & 89.4 & 37.0 & _- & _- & - & - & - & _- & _- & 50.1 & 2.1 & 49.0 & _- \\
\hline Decapod crabs & 0.1 & _- & 7.7 & 1.4 & 49.1 & 23.0 & 21.5 & 11.8 & 24.2 & 1.9 & 37.4 & 0.3 & 22.8 \\
\hline Decapod shrimps & 0.1 & - & - & - & 5.3 & - & 9.2 & - & - & - & 13.4 & - & - \\
\hline Megalop larvae & 0.1 & - & 1.8 & 0.7 & 1.2 & - & 1.1 & 0.1 & _- & 0.1 & _- & 0.3 & - \\
\hline Isopods & 0.1 & 2.5 & 4.8 & - & 4.9 & 17.9 & 0.1 & 0.9 & 3.6 & 6.7 & 7.4 & - & 12.7 \\
\hline Amphipods & 3.2 & 1.3 & 44.4 & 76.3 & 20.7 & 53.1 & 57.8 & 66.1 & 39.7 & 5.7 & 25.8 & 11.7 & 49.0 \\
\hline Copepods & 0.1 & 3.1 & 4.2 & 2.5 & - & - & 4.9 & 10.5 & 0.7 & 1.4 & 1.8 & - & 1.5 \\
\hline Cirripedian cirri & 0.1 & 14.3 & 6.0 & - & - & - & - & - & 3.4 & 1.2 & - & 0.5 & - \\
\hline Unident. Crustacea & - & - & 2.6 & 4.5 & 5.2 & 3.8 & 2.1 & - & - & - & 4.0 & - & - \\
\hline Gastropods & 2.7 & 4.0 & 8.0 & 4.0 & - & - & 2.6 & 1.2 & 8.0 & 1.3 & 3.8 & 38.1 & $5, .9$ \\
\hline Bivalves & 2.7 & 2.9 & 0.9 & 1.3 & - & - & 0.6 & 0.2 & 6.9 & 15.2 & 1.4 & 0.1 & - \\
\hline Polychaetes & 0.8 & 1.4 & 16.3 & 8.1 & 2.1 & - & 0.1 & 5.1 & 5.8 & 2.5 & 2.9 & - & 8.1 \\
\hline Teleosts & - & - & - & - & 11.1 & 2.3 & - & 4.2 & - & - & - & - & - \\
\hline Asteroideans & 0.3 & 0.3 & 1.3 & - & - & - & - & - & - & - & - & - & - \\
\hline Insects & - & - & - & - & - & - & - & - & 2.6 & 9.8 & - & - & - \\
\hline Unident. animal prey & 0.4 & 33.2 & 2.0 & 1.2 & 0.4 & - & - & - & 5.2 & 4.0 & - & - & - \\
\hline Mysid shrimps & - & - & - & - & - & - & - & - & - & - & - & - & - \\
\hline Porifera & - & - & - & - & - & - & - & - & - & - & - & - & - \\
\hline Chitons & - & - & - & - & - & - & - & - & - & - & - & - & - \\
\hline Pycnogonids & - & - & - & - & - & - & - & - & - & - & - & - & - \\
\hline Phyllospadix sp. & - & - & - & - & - & - & - & - & - & - & - & - & - \\
\hline Unidentified & - & - & - & - & - & - & - & - & - & - & - & - & - \\
\hline$B_{i}$ & 0.02 & 0.30 & 0.28 & 0.09 & 0.25 & 0.43 & 0.17 & 0.14 & 0.36 & 0.22 & 0.30 & 0.25 & 0.43 \\
\hline
\end{tabular}

diets of the fishes. Twelve prey categories were common to the diets of Californian fishes examined in this study and the Chilean fishes studied by Muñoz \& Ojeda (1997). Mysids, sponges, chitons, pycnogonids, and the seagrass Phyllospadix sp. were 5 types of prey not observed by Muñoz \& Ojeda (1997) and were relatively rare and infrequent (found in $\leq 4$ species and making up $\leq 12.5 \%$ of diets) in Californian fishes. Four prey types absent in Californian fishes, but consumed by Chilean fishes (Muñoz \& Ojeda 1997), were megalop larvae, barnacle cirri, bivalves, and asteroideans and occurred relatively infrequently in Chilean fishes (found in $\leq 10$ species and $<7 \%$ of diets). Expressing the diets of Chilean intertidal fishes as the average gravimetric dietary contribution of each prey type, instead of summing the biomass of prey types across all individuals as performed by
Muñoz \& Ojeda (1997), produced diet characterizations for some Chilean fish species different from those reported by these 2 authors. Notably, the importance of decapod crabs was reduced for Auchenionchus variolosus, Gobiesox marmoratus, and Graus nigra, and amphipods became the most abundant prey resources in their diets $(53,49$, and $40 \%$, respectively).

The dietary analysis yielded $B_{i}$ and dietary overlap values and statistical recognition of trophic guilds for the 2 assemblages. $B_{i}$ for the carnivorous species in the 2 assemblages (Table 4 ) ranged from the widest in 2 species from California, Artedius lateralis $\left(B_{i}=0.59\right)$ and Clinocottus analis (0.58), and 2 from Chile, Auchenionchus variolosus and Gobiesox marmoratus (0.43 for both), to the narrowest for the Californian species Scytalina cerdale $(\approx 0)$ and the Chilean Helcogram- 
Table 5 . Consumer $\times$ prey resource matrix of intertidal fishes from central California (from present study). Values are percentages of gravimetric diet contribution of each prey category. Levin's standardized niche breadth values ( $B_{i}$, Krebs 1989) shown

\begin{tabular}{|c|c|c|c|c|c|c|c|c|c|c|c|c|c|c|}
\hline & 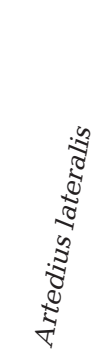 & 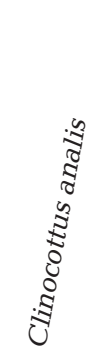 & 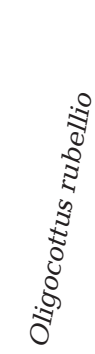 & 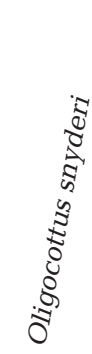 & 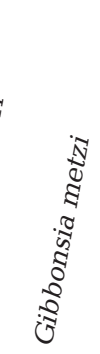 & 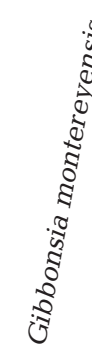 & 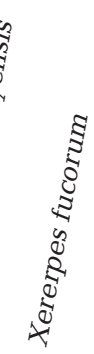 & 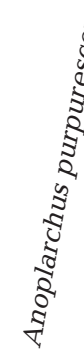 & ఏ̊d & 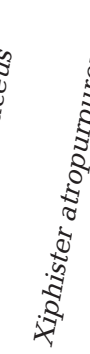 & 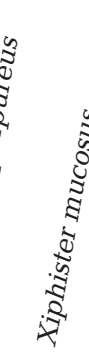 & 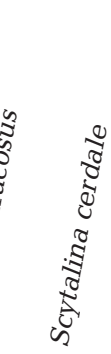 & 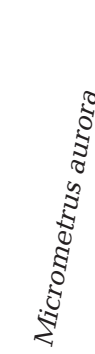 & 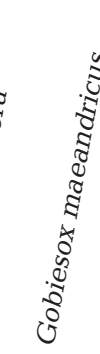 \\
\hline No. fishes examined & 10 & 26 & 7 & 22 & 9 & 18 & 13 & 14 & 12 & 18 & 12 & 19 & 12 & 36 \\
\hline No. with gut content & 9 & 25 & 7 & 20 & 9 & 16 & 7 & 8 & 11 & 16 & 11 & 7 & 10 & 16 \\
\hline Macroalgae & 0.2 & 22.9 & 0.2 & 7.1 & 2.5 & 0.3 & - & 12.5 & 74.4 & 59.5 & 75.7 & - & 42.8 & 2.3 \\
\hline Decapod crabs & 26.1 & 22.3 & 14.3 & 0.9 & 53.9 & 8.5 & - & 12.5 & 2.2 & 1.7 & - & - & - & 15.6 \\
\hline Decapod shrimps & 27.5 & 2.3 & 2.4 & 2.3 & 7.7 & 2.4 & 3.6 & - & - & 6.0 & 0.3 & - & - & - \\
\hline Megalop larvae & - & - & - & - & - & - & - & - & - & - & - & - & - & - \\
\hline Isopods & - & 3.3 & - & - & 1.1 & 5.6 & 0.2 & - & 2.7 & - & 9.1 & - & 1.9 & 0.6 \\
\hline Amphipods & 8.8 & 18.1 & 20.6 & 23.8 & 13.1 & 28.3 & 69.3 & 2.0 & 19.3 & 15.1 & 2.9 & 100.0 & 23.0 & 33.7 \\
\hline Copepods & - & - & - & - & - & - & - & - & - & - & - & - & 4.4 & 4.6 \\
\hline Cirripedian cirri & - & - & - & - & - & - & - & - & - & - & - & - & - & - \\
\hline Unident. Crustacea & - & - & - & 9.5 & 2.4 & 6.3 & 16.1 & - & - & - & - & - & - & 7.4 \\
\hline Gastropods & - & 4.4 & - & 3.3 & 1.9 & 9.4 & 7.2 & - & - & - & 0.1 & - & - & 16.4 \\
\hline Bivalves & - & - & - & - & - & - & - & - & - & - & - & - & - & - \\
\hline Polychaetes & 5.6 & 10.7 & 62.5 & 51.8 & 9.1 & 30.6 & - & 50.0 & 1.3 & 8.8 & - & - & - & 7.5 \\
\hline Teleosts & 31.5 & 3.0 & - & - & - & - & - & - & - & - & - & - & - & 5.7 \\
\hline Asteroideans & - & - & - & - & - & - & - & - & - & - & - & - & - & - \\
\hline Insects & - & - & - & - & - & - & - & - & - & - & - & - & 27.9 & - \\
\hline Unident. animal prey & - & 1.3 & - & 0.8 & - & - & - & - & - & 3.1 & - & - & - & - \\
\hline Mysid shrimps & - & - & - & - & 0.7 & - & - & - & - & - & - & - & - & - \\
\hline Porifera & - & - & - & - & - & - & - & - & - & - & - & - & - & 6.3 \\
\hline Chitons & - & - & - & 0.1 & - & 0.1 & - & - & - & - & - & - & - & - \\
\hline Pycnogonids & - & 1.7 & - & 0.2 & - & 8.6 & - & - & - & - & - & - & - & - \\
\hline Phyllospadix sp. & - & - & - & - & - & - & - & 12.5 & 0.1 & 4.8 & 2.8 & - & - & - \\
\hline Unidentified & 0.4 & 9.9 & - & 0.2 & 7.8 & - & 3.6 & 10.5 & - & 1.1 & 9.1 & - & - & - \\
\hline$B_{i}$ & 0.59 & 0.58 & 0.30 & 0.21 & 0.25 & 0.43 & 0.24 & 0.56 & 0.14 & 0.26 & 0.14 & - & 0.54 & 0.49 \\
\hline
\end{tabular}

moides cunninghami (0.09). Among the omnivores, the most generalized diets were found in Micrometrus aurora (0.54) and Hypsoblennius sordidus (0.30), from California and Chile, respectively, and the most specialized (i.e. more herbivorous) were found in Cebidichthys violaceus and Xiphister mucosus (0.14 each) from California and Scartichthys viridis (0.02) from the Chilean assemblage.

Dietary overlap (similarity) values (Fig. 3) ranged from the least similarity $(S=19 \%)$ between omnivores (4 from California, 4 from Chile) and carnivores (10 from California, 9 from Chile) to the most, among 3 major branches of the remaining carnivorous fishes: 4 Californian species that ate mostly polychaetes (43\%), 3 Californian species and 7 Chilean species that ate mostly amphipods (52\%), and 3 Californian species and 2 Chilean species that consumed larger prey $(S=$ $62 \%$ ), such as crabs, shrimps, and fishes. Four trophic guilds were identified as being statistically distinct based on the employed bootstrapping procedure
(Fig. 3): a carnivore guild with 2 species from each region, a microcarnivore guild with 3 species in California versus 7 species in Chile, a polychaete feeders guild with 4 species in California, but no analog in Chile, and an omnivorous guild with 4 species in California and 3 species in Chile. The carnivore Artedius lateralis from California and the omnivore Hypsoblennius sordidus from Chile had the most distinct diets and failed to group with members of significant trophic guild clusters.

\section{Morphological analysis}

The first 2 principal components (PC1 and PC2) modeled $74 \%$ of the variation of California species in morphospace (Table 6). High species scores on PC1 were associated with large eyes, protrusible jaws, and a deep head. The embiotocid Micrometrus aurora had the highest score on PC1. Low scores 


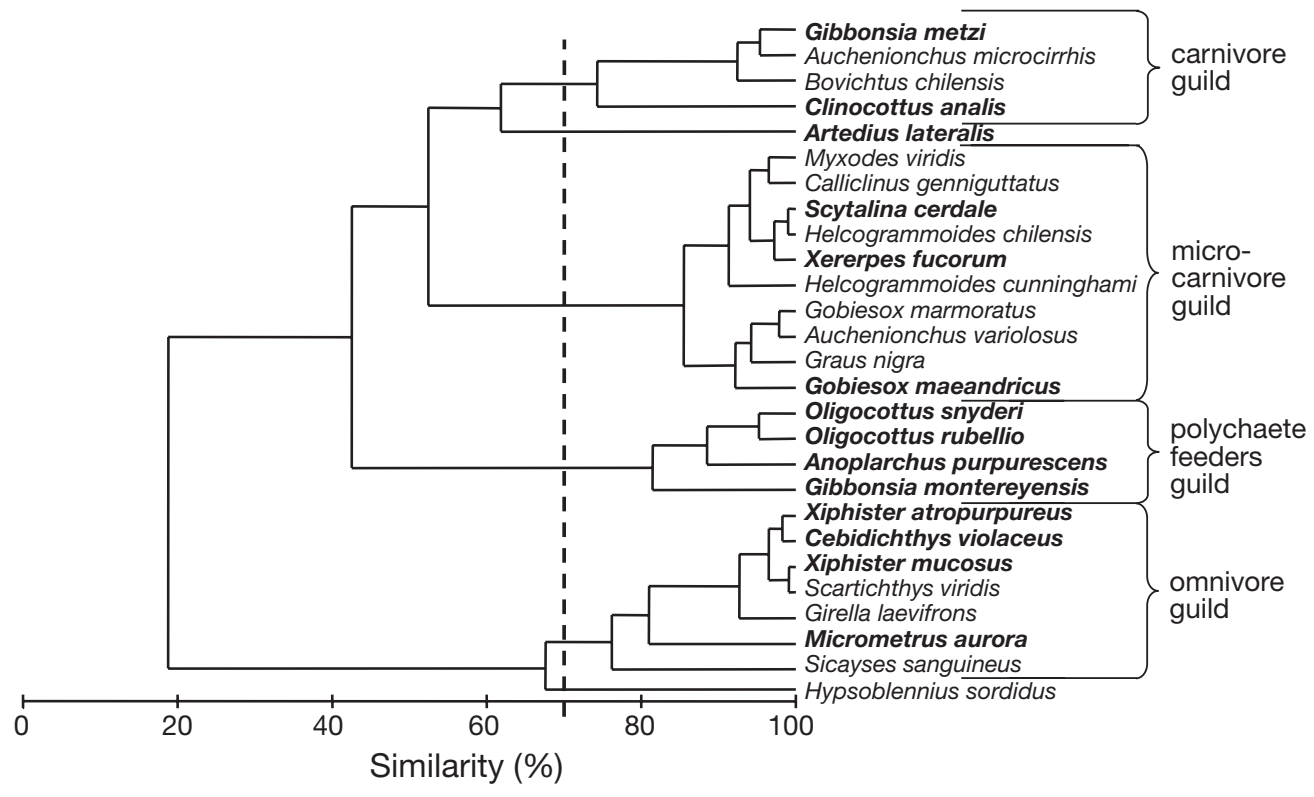

Fig. 3. Diet similarity dendrogram (UPGMA) for the 14 Californian intertidal fish species (bold) and the 13 Chilean intertidal fish species. Chilean fish diets were based on raw dietary data from a study by Muñoz \& Ojeda (1997). Dashed line at $71 \%$ diet similarity indicates the 4 significant trophic guilds determined by a bootstrap procedure

on PC1 were associated with a wide mouth relative to head width and a tall mouth relative to head depth, which was most extreme for Scytalina cerdale. High scores on PC2 were associated with a wider, longer head (e.g. Gobiesox maeandricus) and low scores with a high mouth orientation angle (more terminally opening mouth) and more densely packed gill rakers (e.g. Xererpes fucorum). Euclidean distances calculated from the species scores of the PC axes with eigenvalues $\geq 1.0$ (first 3 axes) revealed that the microcarnivore guild was the most variable in morphospace (3.36), followed by the omnivore guild (2.38), polychaete guild (1.95), and carnivore guild (0.96)

The first 2 PC axes modeled $59 \%$ of the variation of Chilean species in morphospace (Table 6). High scores on PC1 were associated with a wide head and wide mouth relative to head width (e.g. Gobiesox marmoratus), whereas low scores were associated with a deep head and longer gut (e.g. Scartichthys viridis, Girella laevifrons). High scores on PC2 were influenced by larger eyes and increased oral jaw protrusibility, and

Table 6. Results of principal component analyses (PCA) based on morphological features of 14 Californian intertidal fish species, 13 Chilean species, and both faunas combined (27 species). For all axes with eigenvalues $>1.0$ eigenvalues, proportion of variation modeled, cumulative variation modeled and eigenvectors (variable loadings) are shown. Eigenvectors with the strongest loadings are in bold. See Table 2 for description of abbreviated morphological features

\begin{tabular}{|c|c|c|c|c|c|c|c|c|c|c|}
\hline \multirow[b]{2}{*}{ PCA axis } & \multicolumn{3}{|c|}{ - California - } & \multicolumn{4}{|c|}{ - Chile -} & \multicolumn{3}{|c|}{$\begin{array}{c}\text { California and Chile } \\
\text { combined }\end{array}$} \\
\hline & PC1 & PC2 & PC3 & PC1 & PC2 & PC3 & PC4 & PC1 & PC2 & PC3 \\
\hline Eigenvalue & 4.23 & 3.16 & 1.10 & 3.94 & 1.96 & 1.88 & 1.00 & 3.20 & 2.91 & 1.17 \\
\hline Proportion of variation & 0.42 & 0.32 & 0.11 & 0.39 & 0.20 & 0.19 & 0.10 & 0.32 & 0.29 & 0.12 \\
\hline Cumulative variation & 0.42 & 0.74 & 0.85 & 0.39 & 0.59 & 0.78 & 0.88 & 0.32 & 0.61 & 0.73 \\
\hline \multicolumn{11}{|l|}{ Eigenvectors } \\
\hline rel HL & 0.33 & 0.39 & -0.13 & 0.34 & 0.05 & 0.27 & -0.43 & 0.39 & -0.33 & 0.01 \\
\hline rel HD & 0.36 & -0.32 & 0.11 & -0.48 & 0.06 & 0.05 & -0.13 & 0.29 & 0.45 & 0.09 \\
\hline rel HW & 0.24 & 0.48 & -0.05 & 0.44 & 0.21 & 0.24 & -0.08 & 0.31 & -0.46 & -0.16 \\
\hline rel ED & 0.44 & -0.07 & 0.07 & -0.14 & 0.54 & -0.35 & -0.02 & 0.45 & 0.11 & 0.13 \\
\hline rel HLP & 0.41 & 0.03 & 0.37 & 0.04 & 0.34 & -0.50 & 0.28 & 0.30 & -0.01 & 0.46 \\
\hline rel MW & -0.37 & -0.03 & 0.09 & -0.33 & 0.16 & -0.08 & -0.62 & -0.36 & 0.16 & -0.22 \\
\hline rel MH & -0.35 & 0.35 & 0.06 & 0.36 & 0.28 & -0.33 & -0.30 & -0.32 & -0.36 & -0.14 \\
\hline MO & -0.10 & -0.40 & -0.52 & -0.22 & -0.45 & -0.35 & -0.08 & -0.28 & 0.29 & 0.54 \\
\hline GN/GA & -0.01 & -0.45 & 0.47 & -0.20 & 0.40 & 0.40 & 0.43 & 0.16 & 0.34 & -0.49 \\
\hline rel GL & 0.28 & -0.15 & -0.58 & -0.34 & 0.27 & 0.32 & -0.23 & 0.19 & 0.33 & -0.38 \\
\hline
\end{tabular}




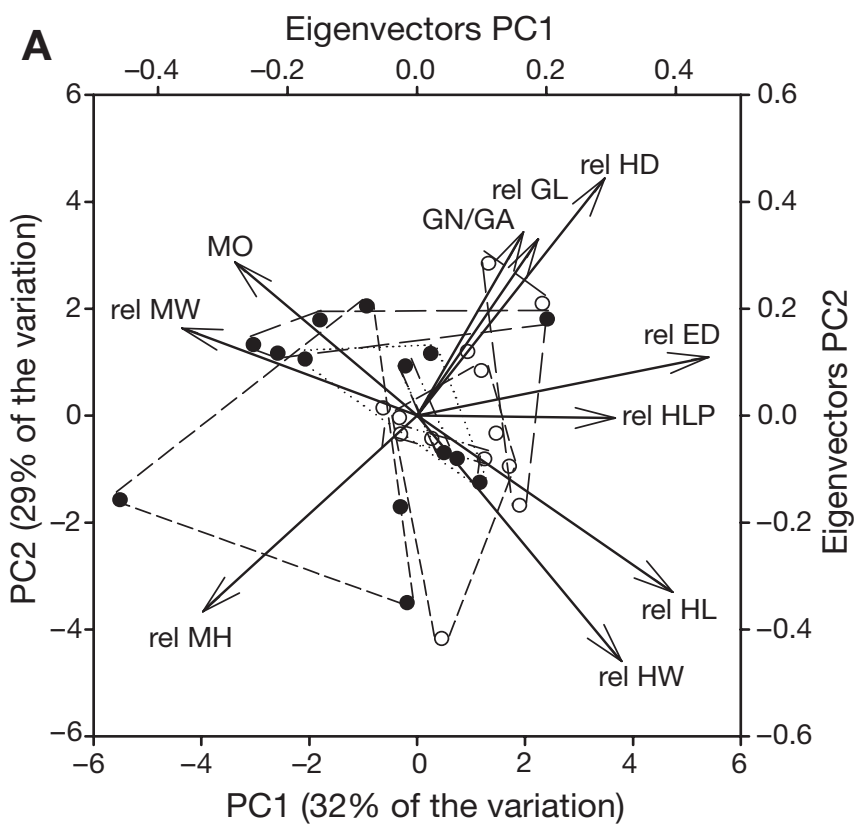

\begin{tabular}{|c|c|}
\hline $\begin{array}{l}\text { - California } \\
\text { o Chile }\end{array}$ & 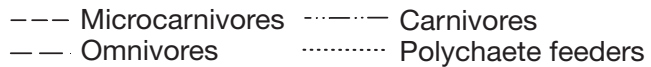 \\
\hline
\end{tabular}

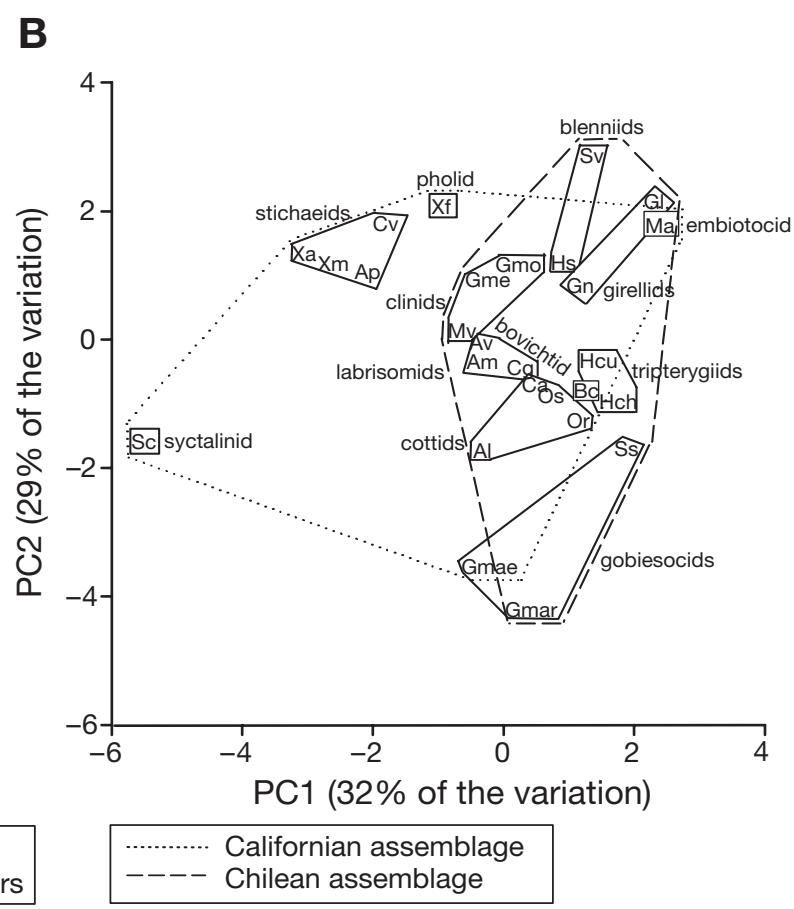

Fig. 4. Plots of scores of Californian and Chilean intertidal fish species on the first 2 principal component (PC) axes based on principal components analysis of morphological features combined from both regions. Eigenvectors of morphological variables are shown as arrows and members of each guild are outlined in (A). In (B) the assemblages are outlined, the species are indicated, and the families are outlined. Sv: Scartichthys viridis; Hs: Hypsoblennius sordidus; Hch: Helcogrammoides chilensis; Hcu: Helcogrammoides cunninghami; Am: Auchenionchus microcirrhis; Av: Auchenionchus variolosus; Cg: Calliclinus geniguttatus; Mv: Myxodes viridis; Gn: Graus nigra; Gl: Girella laevifrons; Bch: Bovichtus chilensis; Ss: Sicyases sanguineus; Gmar: Gobiesox marmoratus; Al: Artedius lateralis; Ca: Clinocottus analis; Or: Oligocottus rubellio; Os: Oligocottus snyderi; Gme: Gibbonsia metzi; Gmo: Gibbonsia montereyensis; Xf: Xererpes fucorum; Ap: Anoplarchus purpurescens; Cv: Cebidichthys violaceus; Xa: Xiphister atropurpureus; Xm: Xiphister mucosus; Sc: Scytalina cerdale; Ma: Micrometrus aurora; Gmae: Gobiesox maeandricus

the tripterygiids Helcogrammoides cunninghami and $H$. chilensis had the highest PC2 scores. Low scores on PC2 were most influenced by a more terminally opening mouth, and the clinid Myxodes viridis had the lowest PC2 score. Euclidean distances of species scores on $\mathrm{PC}$ axes with eigenvalues $\geq 1.0$ (first 4 axes) revealed the greatest morphological variation in the microcarnivore guild (3.39), followed by the omnivore guild (2.28), and, lastly, the carnivore guild (0.84).

The combined interregional PCA modeled $61 \%$ of the variation in the first $2 \mathrm{PC}$ axes (Table 6). The first axis was influenced most by eye diameter, head length, mouth height, and mouth width. Relative head depth, gill raker density, relative mouth height, relative head width, and relative head length were the most important eigenvectors for PC2. Considerable overlap in morphospace between the 2 regions was revealed (Fig. 4). The most extreme morphologies were of Scytalina cerdale from California, with the lowest score on PC1, and of Gobiesox marmoratus from Chile and G. maeandricus from California, with the lowest scores on PC2. The morphological variation modeled by the first 2 PC axes could not clearly distin- guish feeding guilds from either region on the basis of overall morphology (Fig. 4), and the overall morphological pattern was more closely tied to taxonomic affiliation. Euclidean distances of the species scores of the first $3 \mathrm{PC}$ axes revealed similar morphological variation between the 2 faunas (California $=4.38$, Chile = 4.59) .

The stepwise LDA models using morphology to predict guild membership correctly classified $100 \%$ of the species of both fish faunas $(29 \%$ by jackknifed classification for Californian species and $77 \%$ by jackknifed classification for Chilean species) (Table 7). The LDA models of the Californian and Chilean assemblages used some of the same morphological variables: GN/GA, rel HD, and rel HW (Table 7, Figs. 5 \& 6). The same pattern of gill raker density was seen between the 2 assemblages, with carnivores having the lowest density and omnivores having the highest; however, relative head depth was greater for carnivores in California than for omnivores in Chile. Omnivores in California had the lowest relative head width, but, in Chile, the relative head width of omnivores was among the largest. Relative mouth width, relative head length, 
Table 7. Linear discriminant analysis (LDA) models using morphological variables to predict guild membership in the Californian and Chilean intertidal fish assemblages. Variables used in the models are listed with their $F$-to-remove values and their means within each group (guild). See Table 2 for description of abbreviated morphological features. A. lateralis: Artedius lateralis; H. sordidus: Hypsoblennius sordidus. F-to-remove: LDA statistic which shows how much a morphological variable contributes to the overall model

\begin{tabular}{|c|c|c|c|c|c|c|}
\hline $\begin{array}{l}\text { Morphological } \\
\text { variable }\end{array}$ & $F$-to-remove & Carnivores & Omnivores & $\begin{array}{l}\text { - Group means } \\
\text { Microcarnivores }\end{array}$ & Polychaete feeders & A. lateralis \\
\hline \multicolumn{7}{|c|}{ California Wilk's Lambda $<0.001 ; \mathrm{df}=28,12 ; \mathrm{p}=0.0052$} \\
\hline GN/GA & 30.7 & 0.84 & 1.85 & 1.60 & 1.45 & 0.64 \\
\hline Rel MW & 20.9 & 0.55 & 0.62 & 0.61 & 0.59 & 0.64 \\
\hline Rel HD & 18.8 & 0.71 & 0.66 & 0.49 & 0.69 & 0.49 \\
\hline Rel HL & 13.8 & 0.28 & 0.18 & 0.19 & 0.26 & 0.38 \\
\hline Rel ED & 13.2 & 0.21 & 0.21 & 0.15 & 0.23 & 0.21 \\
\hline Rel HW & 6.8 & 0.16 & 0.08 & 0.14 & 0.16 & 0.26 \\
\hline $\mathrm{MO}$ & 4.7 & 75.75 & 69.11 & 69.67 & 69.38 & 84.50 \\
\hline & Total & Carnivores & Omnivores & Microcarnivores & Polychaete feeders & A. lateralis \\
\hline $\begin{array}{l}\text { Correct } \\
\text { classifications (\%) }\end{array}$ & 100 & 100 & 100 & 100 & 100 & 100 \\
\hline $\begin{array}{l}\text { Jackknife } \\
\text { classifications (\%) }\end{array}$ & 29 & 0 & 25 & 67 & 0 & 100 \\
\hline $\begin{array}{l}\text { Morphological } \\
\text { variable }\end{array}$ & $F$-to-remove & Carnivores & Omnivores & $\begin{array}{l}\text { - Group means - } \\
\text { Microcarnivores }\end{array}$ &  & H. sordidus \\
\hline Chile Wilk's Lambd & $\mathrm{a}=0.012 ; \mathrm{df}=$ & 2,$16 ; p=0.0$ & & & & \\
\hline Rel HD & 21.4 & 0.60 & 0.73 & 0.65 & & 0.85 \\
\hline Rel GL & 19.4 & 0.72 & 1.58 & 0.61 & & 0.88 \\
\hline Rel HW & 8.9 & 0.17 & 0.20 & 0.20 & & 0.16 \\
\hline GN/GA & 8.5 & 1.26 & 3.71 & 2.41 & & 1.35 \\
\hline & Total & Carnivores & Omnivores & Microcarnivores & & H. sordidus \\
\hline $\begin{array}{l}\text { Correct } \\
\text { classifications (\%) }\end{array}$ & 100 & 100 & 100 & 100 & & 100 \\
\hline $\begin{array}{l}\text { Jackknife } \\
\text { classifications (\%) }\end{array}$ & 77 & 100 & 67 & 86 & & 0 \\
\hline
\end{tabular}

relative eye diameter, and mouth orientation angle also were important variables for the California model. Relative gut length was a significant predictor in the model for Chilean fishes, but not for Californian species.

The second LDA procedure tested the ability of morphological features to predict the broadest dietary differences (carnivorous fishes vs. omnivorous fishes) in each assemblage. The stepwise LDA models produced similar classification success rates for each assemblage: 93\% (86\% jackknifed classifications) in California (only Xererpes fucorum was misclassified) and $100 \%$ ( $72 \%$ jackknifed classifications) in Chile (Table 8). The models for both regions used relative gut length and relative head width, with omnivores having longer guts and wider heads; however, almost no difference in head length was found between omnivores and carnivores in Chile. The model for Chile also incorporated relative mouth width and head length.

Three regressions between individual prey items and morphological attributes were found to be statistically significant after correcting for 10 multiple comparisons. Algae and relative gut length were positively correlated in both Chile $\left(\mathrm{r}^{2}=0.59, \mathrm{p}=0.001\right)$ and Cali- fornia $\left(r^{2}=0.30\right.$, although not significant, $\left.p=0.042\right)$. Gastropods and mouth orientation angle were negatively correlated in California $\left(r^{2}=0.59, p=0.001\right)$ and Chile $\left(\mathrm{r}^{2}=0.36\right.$, although not significant, $\mathrm{p}=$ 0.012 ), and this relationship was influenced mainly by gobiesocids in each region. In Chile, consumption of algae was positively correlated with gill raker density $\left(r^{2}=0.69, p=0.0001\right)$. Several other relationships between prey taxa and morphological variables with $r^{2} \geq 0.30$ were found, although none was significant after sequential-Bonferroni multiple-comparison corrections. In both California and Chile, amphipods were positively correlated with mouth height $\left(\mathrm{r}^{2}=0.32, \mathrm{p}=\right.$ $0.037 ; r^{2}=0.35, p=0.033$ ) and, in Chile only, were negatively correlated with gill raker density $\left(r^{2}=0.38, p=\right.$ $0.013)$ and relative gut length $\left(r^{2}=0.41, p=0.018\right)$. In Chile, polychaetes were positively correlated with mouth height $\left(r^{2}=0.31, p=0.049\right)$, and algae were negatively correlated $\left(r^{2}=31, p=0.045\right)$. In California, insect prey were positively correlated with relative eye diameter $\left(\mathrm{r}^{2}=0.36, \mathrm{p}=0.022\right)$ and head length protruded $\left(\mathrm{r}^{2}=0.31, \mathrm{p}=0.039\right)$, but this relationship may be spurious because insects were only consumed 


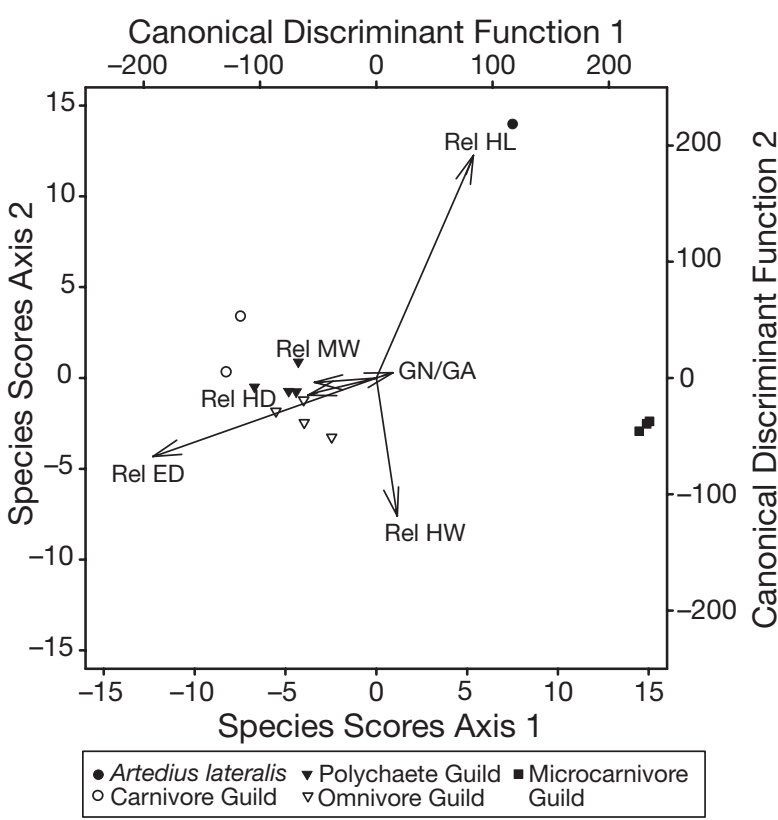

Fig. 5. Plot of scores for Californian intertidal fish species on the first 2 canonical factors from a linear discriminant analysis model using morphology as a predictor of guild membership. Discriminant functions of morphological variables are shown as arrows (abbreviations: see Table 2)

by 1 species, Micrometrus aurora. In Chile, insects were positively correlated with relative gut length $\left(\mathrm{r}^{2}=\right.$ 0.45, $\mathrm{p}=0.013$ ). In California, copepods were positively correlated with head length protrusibility $\left(\mathrm{r}^{2}=\right.$ 0.40, $\mathrm{p}=0.015$ ). In Chile, isopods and decapod shrimps were both negatively correlated with gill raker density $\left(\mathrm{r}^{2}=0.41, \mathrm{p}=0.043 ; \mathrm{r}^{2}=0.41, \mathrm{p}=0.018\right)$. In Chile, gastropods were positively correlated with relative head width $\left(\mathrm{r}^{2}=0.30, \mathrm{p}=0.05\right)$, relative mouth width $\left(\mathrm{r}^{2}=0.40, \mathrm{p}=0.021\right)$, and gill raker density $\left(\mathrm{r}^{2}=0.30, \mathrm{p}=0.053\right)$; the latter relationship is influenced strongly by Sicyases sanguineus.

Tests of dietary, morphological, and phylogenetic similarity using the RELATE routine (Table 9) yielded trends, although none of the randomization tests were significant after sequential-Bonferroni correction for 15 table-wide comparisons. Both within and between assemblages, the weakest correlations found were between diet and phylogeny and, for Chile only and between assemblages, were found between diet and morphology when all morphological variables were used (Table 8). A stronger correlation between dietary overlap and overall morphological similarity was found in the Californian assemblage; however, when morphological similarity was calculated using

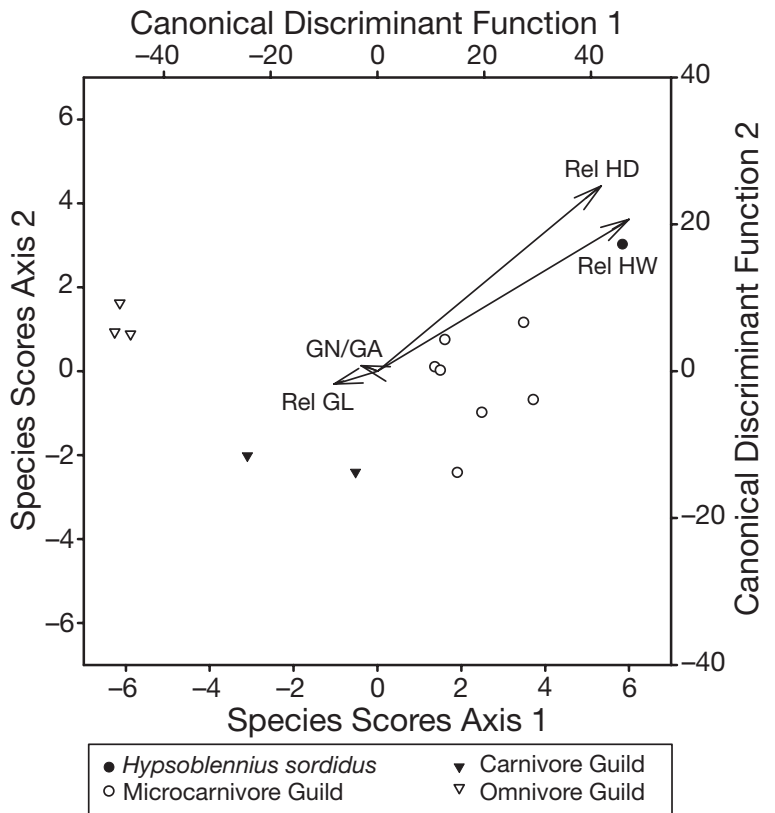

Fig. 6. Plot of scores for Chilean intertidal fish species on the first 2 canonical factors from a linear discriminant analysis model using morphology as a predictor of guild membership. Discriminant functions of morphological variables are shown as arrows (abbreviations: see Table 2)

only variables identified from LDA, the correlations between morphology and diet increased in both the Californian and the Chilean assemblages, but not between assemblages (Table 9, Fig. 7). Morphological similarity, both overall similarity and similarity calculated from variables identified from LDA, was more

Table 8. Linear discriminant analysis models using morphological variables to predict omnivores and carnivores in the Californian and Chilean intertidal fish assemblages. Omnivore and carnivore groupings based on the diet dendrogram (Fig. 3). Variables used in the models are listed with their $F$-to-remove values and their means within each group (carnivores or omnivores). See Table 2 for description of abbreviated morphological features

\begin{tabular}{|lccc|}
\hline \multirow{2}{*}{$\begin{array}{l}\text { Morphological } \\
\text { variable }\end{array}$} & \multicolumn{2}{c|}{ Group means } \\
& & Carnivores & Omnivores \\
California Wilk's Lambda $=0.489 ; \mathrm{df}=2$, & $11 ; \mathrm{p}=0.0195$ \\
Rel GL & 7.13 & 0.78 & 1.00 \\
Rel HW & 5.8 & 0.17 & 0.08 \\
Correct classifications (\%) & 93 & 90 & 100 \\
Jackknife classifications (\%) & 86 & 90 & 75 \\
& & & \\
Chile Wilk's Lambda =0.316; df $=2,11$ & $16 ; \mathrm{p}=0.0031$ & 0.19 \\
Rel HW & 17.9 & 0.19 & 1.41 \\
Rel GL & 15.1 & 0.63 & 0.45 \\
Rel MH & 14.0 & 0.67 & 0.29 \\
Rel HL & 7.0 & 0.29 & 100 \\
Correct classifications (\%) & 100 & 100 & 75 \\
Jackknife classifications (\%) & 72 & 100 & \\
\end{tabular}


correlated with phylogenetic distance than with diet in California and between assemblages; however, in Chile, LDA-selected morphological variables were correlated more with diet than phylogenetic distance (Table 9).

\section{DISCUSSION}

The results of this study support the hypothesis that dietary guild structure is not phylogenetically constrained within the intertidal fish assemblages of central California and central Chile. Additionally, this study supported the hypothesis that similar guild structures exist for these 2 phylogenetically distinct assemblages. Our interregional comparison, which used functional prey groupings, incorporated several sites per region, attempted to characterize broadly the diet of each species across the size ranges commonly encountered in the intertidal environment, and provided evidence of guild-level concordance between 2 largely unrelated fish faunas. In the Californian assemblage, morphological features were best at separating omnivorous fishes from carnivorous species, whereas, in Chile, morphological features were best at predicting guild-level dietary patterns. Evaluation of the morphological features of the fishes within each assemblage provided partial support for the hypothesis that some of these features were associated with the feeding ecology of the fishes rather than with their phylogenetic relationships. In California, consumer morphology was associated with both dietary overlap and phylogenetic relatedness, whereas, in Chile, consumer morphology was related more to dietary overlap than phylogenetic relatedness. The hypothesis, however, that morphological similarities would exist between fishes from California and Chile that were members of analogous feeding guilds was not supported. No relationship between interregional dietary overlap and morphological similarity was found, but interregional morphological similarities (and differences) were associated with phylogenetic relatedness.

The objective comparison of dietary overlap between fishes within and between Californian and Chilean assemblages revealed an example of ecological convergence in unrelated fish assemblages. Many of the same consumer niches were found to exist in both assemblages despite their separate phylogenetic histories. The dietary overlap between these 2 unre-
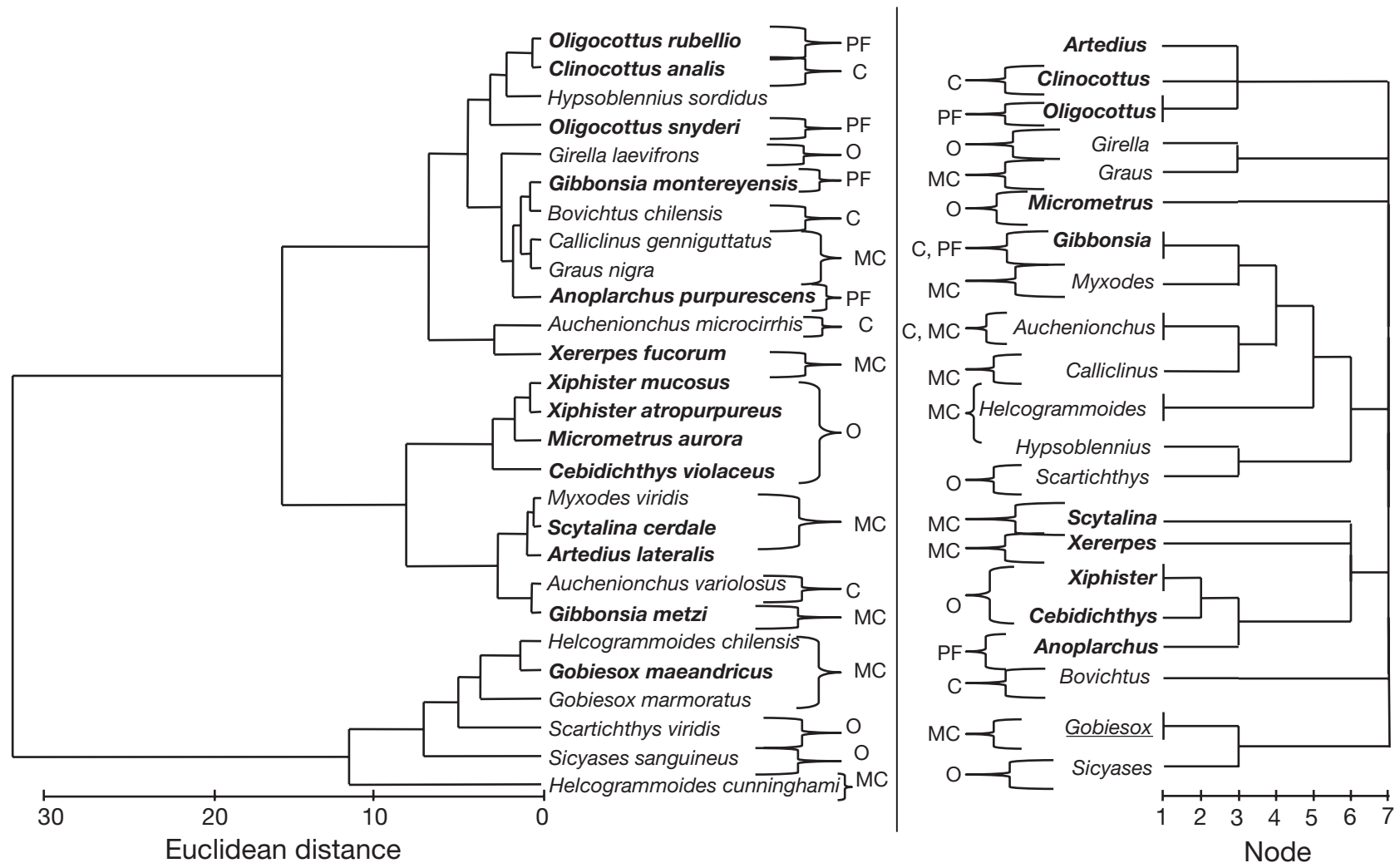

Fig. 7. UPGMA dendrogram (left) of morphological similarity of intertidal fishes from California (bold) and Chile based on the following morphological variables: GN/GA, rel MW, rel HD, rel HL, rel ED, rel HW, rel GL, and MO (see Table 2 for definitions and descriptions). Phylogenetic similarity of the genera in California (bold) Chile (plain text), and both regions (underlined) is shown on the right (guild membership-C: carnivores; MC: microcarnivores; O: omnivores; PC: polychaete feeders) 
Table 9. Comparison of dietary similarity (Pianka's 1973 index) versus phylogenetic distance (see Fig. 2), morphological distance (Euclidean distance) versus dietary similarity, and morphological distance versus phylogenetic distance within each fish assemblage (California and Chile) and between assemblages using the RELATE (Clarke \& Warwick 1991) routine. Morphological similarity was calculated: (1) using all variables investigated and (2) using only the variables found through linear discriminant analysis (LDA) to be important predictors of diet. Sample statistics ( $\rho$ ) and p-values for their permutation tests are given for each comparison. None of the permutation tests was significant after correction for table-wide comparisons

\begin{tabular}{|c|c|c|c|}
\hline & California & Chile & Both assemblages \\
\hline Diet-Phylogeny & $\rho=0.046, p=0.292$ & $\rho=0.004, p=0.400$ & $\rho=0.032, p=0.283$ \\
\hline $\begin{array}{l}\text { Diet-Morphology, } \\
\text { all variables }\end{array}$ & $\rho=0.224, p=0.036$ & $\rho=-0.037, p=0.551$ & $\rho=0.044, p=0.231$ \\
\hline $\begin{array}{l}\text { Diet-Morphology, } \\
\text { LDA-selected variables }\end{array}$ & $\rho=0.221, p=0.039$ & $\rho=0.537, p=0.006$ & $\rho=0.044, p=0.241$ \\
\hline $\begin{array}{l}\text { Morphology-Phylogeny, } \\
\text { all variables }\end{array}$ & $\rho=0.232, p=0.041$ & $\rho=0.094, p=0.215$ & $\rho=0.151, p=0.028$ \\
\hline $\begin{array}{l}\text { Morphology-Phylogeny, } \\
\text { LDA-selected variables }\end{array}$ & $\rho=0.232, p=0.032$ & $\rho=0.224, p=0.107$ & $\rho=0.151, p=0.035$ \\
\hline
\end{tabular}

lated assemblages parallels the results of comparisons between freshwater fish assemblages, such as distantly related cichlids (Winemiller et al. 1995) and gymnotiform and mormyriform fishes (Winemiller \& Adite 1997). Few assemblage-wide comparisons of intertidal fish diets exist. Cross (1982) found general similarities between the number of omnivores and carnivores between the unrelated intertidal fish faunas of Washington, southern California, and France. Stepien (1990) examined the dietary habits of most of the same Chilean species as Muñoz \& Ojeda (1997) and suggested that a similar number of omnivorous species, but in lower abundance, may exist north of Point Conception in the Oregonian biogeographic province. Our results corroborate her findings of similar diversity of omnivores, but not for abundance because, at San Simeon, members of the omnivorous feeding guild, Xiphister atropurpureus, X. mucosus, and Cebidichthys violaceus, are among the most numerically abundant species (M.H.H. unpubl. data).

Central California and central Chile contain a similar number of strictly carnivorous species: 10 in California and 9 in Chile, and the same number (4) of omnivorous species. Herbivory has been well documented for 2 members of the omnivore guild, Cebidichthys violaceus and Xiphister mucosus, that were found to consume the most algae in the Californian assemblage (Horn \& Ojeda 1999). Omnivory has been reported previously in the stichaeid $X$. atropurpureus (Cross 1981) and in the embiotocid Micrometrus aurora (Eschmeyer et al. 1983). Several studies have been conducted on the herbivorous blenniid Scartichthys viridis in Chile (Ojeda \& Muñoz 1999, Muñoz \& Ojeda 2000). The 2 other members of the omnivore guild in Chile, Girella laevifrons and Sicyases sanguineus, are more omnivorous (Stepien 1990, Varas \& Ojeda 1990).
S. sanguineus, like some other intertidal clingfishes, also consumes limpets (Stepien 1990, Varas \& Ojeda 1990). The fourth omnivore in Chile, Hypsoblennius sordidus, was not a member of the statistically significant omnivore guild and also may consume sea anemones (Muñoz \& Ojeda 1997).

Both assemblages contain carnivorous species that consume mostly gammarid amphipods and those that eat larger invertebrate prey, mainly crabs and shrimps. Polychaete prey, however, were consumed by several species of Californian fishes to a much greater extent than their Chilean counterparts. Other studies on the dietary habits of Oligocottus snyderi (Yoshiyama 1980, Grossman 1986) and Gibbonsia montereyensis (Grossman 1986), 2 species that were found to be members of the polychaete feeders guild in the present study, suggest that these species may consume more amphipods and fewer polychaetes in at least some localities. As in our study, polychaetes and algae have been reported in the diet of Anoplarchus purpurescens (Hart 1973, Cross 1981, Yoshiyama \& Darling 1982) and O. rubellio (Johnston 1954). Polychaetes are consumed by several species in Chile, but contribute little to their overall diets (Stepien 1990, Varas \& Ojeda 1990, Muñoz \& Ojeda 1997, 1998). The present study did not address whether the differences in polychaete consumption between the 2 assemblages is a result of the preferences of the consumers, the microhabitats in which they feed, or differences in the prey availability between the habitats of these 2 environments.

Members of the carnivore guilds in California and Chile are distinguished by their consumption of crabs. Yoshiyama (1980) found that crabs, along with amphipods and algae, were an important prey resource for Clinocottus analis, but Grossman (1986) found that C. analis eats mostly polychaetes and shrimp. Gross- 
man (1986), with large sample sizes, also found that Gibbonsia metzi at Dillon Beach, California, consumed mainly the isopods Idotea spp. Isopods were not found to be a major prey resource of any of the Californian species in the present study. Although the cottid Artedius lateralis was not assigned to the crab guild, it was most similar in diet to members of this guild. Several other studies have noted the importance of crabs, shrimps, and fishes in the diet of this fish (Yoshiyama 1980, Cross 1981, Grossman 1986). Crabs have been found to be an important dietary component for several Chilean species in addition to the 2 members of the crab guild, e.g. Auchenionchus variolosus, Graus nigra, and Helcogrammoides cunninghami (Stepien 1990, Varas \& Ojeda 1990, Muñoz \& Ojeda 1998).

Members of the microcarnivore guild of both regions rely heavily on gammarid amphipods in their diets. In California, amphipods were the most abundant dietary item for Scytalina cerdale and Xererpes fucorum. Grossman (1986) also found amphipods to be the most important food for X. fucorum. The graveldiver $S$. cerdale has not been studied extensively in California and has been a rare component of most collections (e.g. Yoshiyama et al. 1986, 1987). Amphipods also were the most important component of the diet of the northern clingfish Gobiesox maeandricus in the present study. Clingfishes are reputed to consume limpets (Norton \& Cook 1999), and we found limpets to be the second most important prey for G. maeandricus, which consumed more limpets than any other Californian species in our study. Not surprisingly, the congener of G. maeandricus in Chile, G. marmoratus, has a diet (amphipods and limpets) similar to that of G. maeandricus and was found to be a member of the Chilean microcarnivore guild.

We found feeding guild structure in the 2 assemblages to be independent of phylogenetic relationships, despite their phylogenetic differences. Presently, however, there are few resolved phylogenies for intertidal fish species (Horn 1999), including the species of these 2 assemblages. The resolving power of the phylogeny used in this study did not reveal any assemblage-wide diet-phylogeny pattern. In the Californian assemblage, however, the dietary habits of the 4 members of the family Stichaeidae parallel their phylogenetic associations. The 3 most herbivorous stichaeids, Cebidichthys violaceus, Xiphister atropurpureus, and $X$. mucosus, are members of the tribe Xiphisterini, whereas the carnivorous stichaeid Anoplarchus purpurescens is a member of the Alectriini (see Stoddard 1985, German et al. 2004). Other species also may show dietary patterns that parallel phylogenetic associations in the 2 assemblages; however, these patterns cannot be revealed until the evolutionary relationships among the species present are understood more fully.
A robust phylogeny also is needed to determine the degree of convergent or divergent evolution between unrelated assemblages after diet-morphological patterns have been identified (Winemiller et al. 1995). Our identification of morphologies that are common or unique to consumer guilds within each region, however, is a starting point for researchers that are interested in determining possible adaptations or constraints for consuming particular types of prey.

Some difficulties arise when an ecomorphological comparison between 2 isolated fish assemblages is made. Ecological performance, in this case, dietary habit, needs to be appropriately detailed to make a robust comparison of feeding ecology and morphology between assemblages (Winemiller et al. 1995). The discrepancies that exist between the characterizations of dietary habits of some of the intertidal fish species in the Californian and Chilean assemblages underscore the challenges involved in relating structural features of animals to their ecological habits. Fishes may change their diets seasonally, perhaps in response to seasonal changes in productivity and prey availability (Grossman 1986), and ontogenetic changes in diet are known to occur in some fish species. Most of the herbivorous fishes studied have been shown to be more carnivorous or omnivorous as juveniles (e.g. Horn et al. 1982, Barry \& Ehret 1993, Sturm \& Horn 1998, Aldana et al. 2002, German et al. 2004). Nevertheless, Scartichthys viridis has been shown to be herbivorous as soon as settlement occurs, but a shift in the species of algae consumed occurs during ontogeny (Muñoz \& Ojeda 2000). Another species in the Chilean intertidal assemblage, Sicyases sanguineus, is exceptional in that the intertidal juveniles apparently consume a fair amount of algae, but the adults are carnivorous (Cancino \& Castilla 1988). Ontogenetic changes in carnivorous fishes, such as switching from small prey taxa (e.g. harpacticoid copepods) to larger prey (e.g. caridean shrimps), have been shown for several carnivorous intertidal fish species (Grossman 1986, Kotrschal \& Thomson 1986, Wells 1986, Horn \& Gibson 1988, Norton 1991, Muñoz \& Ojeda 1998, Norton \& Cook 1999). Intertidal fishes also vary in their use of the intertidal environment (transient vs. residents), and some species become more subtidal with ontogeny (Gibson \& Yoshiyama 1999). Thus, the spectrum of prey resources available to some transient intertidal species may change as they move to subtidal habitats. Also, prey resources may vary spatially and temporally in the intertidal zone; thus, it is not surprising that both seasonal (Grossman 1986) and geographical differences (Aldana et al. 2002) in the diets of intertidal fishes have been demonstrated. Even though several factors may confound dietary analysis, our results nevertheless revealed a within-assemblage, but not 
a between-assemblage relationship between morphology and diet.

The use of LDA in the present study revealed that diet is predicted by different sets of morphological features in each assemblage. Several morphology-diet patterns, however, were found to be common to both assemblages. Relative gut length tended to be longer in omnivorous fishes of both California and Chile. Many other studies have demonstrated that omnivorous, herbivorous, and detritivorous fishes have longer guts relative to other species in their assemblages (Winemiller 1991, Piet 1998, Hugueny \& Pouilly 1999, Delariva \& Agostinho 2001, Xie et al. 2001, German \& Horn 2006). Surprisingly, gill raker density, a trait often associated with fishes consuming small invertebrates or detritus (Motta et al. 1995a, Xie et al. 2001), was highest in the omnivorous fishes of both assemblages. The oral jaws of the omnivorous intertidal fishes of central California and central Chile, however, open differently. The omnivorous stichaeids and the embiotocid Micrometrus aurora have mouths that open terminally, whereas the omnivorous fishes from Chile have mouths that open more subterminally. The blenniids Scartichthys viridis and Hypsoblennius sordidus are characterized by strong jaws, with closely set incisiform teeth that are able to remove algae and animals from the substratum (Cancino et al. 1999, Horn \& Ojeda 1999). The gobiesocid Sicyases sanguineus also has strong jaws and uses its teeth, along with leverage provided by its pelvic disc, to remove attached benthic prey (Paine \& Palmer 1978, Norton \& Cook 1999).

Morphology was a better predictor of significant trophic guilds for Chilean than for Californian assemblages. Carnivorous fishes in both regions tended to have wider heads and, in California, tended to have longer heads, features that may be related to the size of the large invertebrate prey consumed. Not surprisingly, carnivorous species in both assemblages tended to have larger relative mouth height, a feature associated with gape size, than omnivores. But, interestingly, members of the microcarnivore guild of both regions, which ate mostly gammarid amphipods, had the largest relative mouth heights in the assemblage. Scytalina cerdale in California and tripterygiids in Chile have large mouth heights relative to small heads, and Gobiesox in both regions has a large gape and a wide but shallow head. Members of the carnivore guild from both regions, as well as Artedius lateralis, were generally characterized by having the lowest density of gill rakers. Relatively low gill raker density also has been found in a number of carnivores in other systems (Labropoulou \& Eleftheriou 1997, Xie et al. 2001).

Two features, eye diameter and jaw protrusibility, were not associated with feeding in either assemblage.
Eye diameter may be phylogenetically constrained, or may have many other functional associations, such as time of activity (diurnal vs. nocturnal), predator avoidance, or light availability in a specific microhabitat. Some authors have found relatively little correlation between morphology and the types of prey consumed and suggest that morphology may be more tightly correlated with the foraging microhabitat (Motta et al. 1995a, Winemiller et al. 1995). Surprisingly, jaw protrusibility was not associated with specific types of prey. Highly protrusible jaws may be characteristic of ramfeeding fishes that eat more elusive prey items (e.g. fish, shrimp) and strike their prey from a greater distance (Norton 1995, Norton \& Cook 1999, Wainwright 1999). Jaw protrusibility also may be associated with suction-feeding fishes that rapidly expand their buccal cavities to ingest prey, and it may be difficult to differentiate between the morphologies associated with ram- and suction-feeding (Wainwright 1999). In the Californian and Chilean assemblages, few fishes were found to be feeding on elusive prey. The cottid Artedius lateralis in California is a ram-feeding cottid (Norton 1995, Norton \& Cook 1999), but the omnivorous embiotocid was found to have greater relative jaw protrusibility, possibly for suction feeding on invertebrate prey. Some morphological patterns may be masked when phylogenetically diverse groups are compared.

Future studies of these 2 assemblages should focus on the performance of guild members and attempt to compare species within a phylogenetic context. Ecomorphological studies are the starting points for functional morphology experiments in the laboratory that test the mechanistic basis for diet-morphology associations (Motta et al. 1995b). Functional morphology comparisons on 2 sets of unrelated taxa (e.g. Norton \& Brainerd 1993) provide a compelling opportunity to make an independent comparison of the role of specific morphological attributes in prey selection. Direct tests of convergent and divergent evolution of fishes within intertidal assemblages will be possible when detailed phylogenies of intertidal species and their subtidal relatives are available.

Acknowledgements. We thank D. Eernisse and S. Murray for suggestions about the study design; K. Messer for statistical advice; C. Boyle, J. Boyle, T. E. Cox, A. Gawlicka, D. German, B. Johnson, K. Kim, and M. Saba for help in the field; A. Muñoz and F. P. Ojeda for the raw dietary data from their 1997 study; and F. P. Ojeda, C. Hernandez, V. Lobos, F. Ogalde, P. Vergara, and J. Rojas for providing Chilean fish specimens. Additional specimens were obtained on loan from the Los Angeles County Natural History Museum and the Gulf Coast Research Laboratory Museum. Financial assistance was provided by the American Institute of Fishery Research Biologists, Sigma Xi, and by the Associated Students and Department of Biological Science at California State University, Fullerton. 


\section{LITERATURE CITED}

Aldana M, Pulgar JJ, Ogalde F, Ojeda FP (2002) Morphometric and parasitological evidence for ontogenetic and geographical dietary shifts in intertidal fishes. Bull Mar Sci 70:55-74

Andersen AA (1997) Functional groups and patterns of organization in North American ant communities: a comparison with Australia. J Biogeogr 24:433-460

Arroyo MTK, Cavieres L, Marticorena C, Muñoz-Schick M (1995) Convergence in the Mediterranean floras in central Chile and California: insights from comparative biogeography. In: Arroyo MTK, Zedler PH, Fox BJ (eds) Ecology and biogeography of Mediterranean ecosystems in Chile, California, and Australia. Springer-Verlag, New York, p 43-88

Barry JP, Ehret MJ (1993) Diet, food preference, and algal availability for fishes and crabs on intertidal reef communities in southern California. Environ Biol Fishes 37:75-95

Brooks DR, McLennan DA (1991) Phylogeny, ecology and behavior: a research program in comparative biology. University of Chicago Press, Chicago, IL

Cancino JM, Castilla JC (1988) Emersion behaviour and foraging ecology of the common Chilean clingfish Sicyases sanguineus (Pisces: Gobiesocidae). J Nat Hist 22:249-261

Cancino C, de la Hoz E, Farias K (1999) Morfología cefálica de Hypsoblennius sordidus (Bennet, 1828) (Perciformes, Blenniidae): un blénido omnívoro. Rev Biol Mar Oceanogr 34:167-180

Clarke KR, Warwick RM (2001) Change in marine communities: an approach to statistical analyses and interpretation. PRIMER-E, Plymouth, p 172

Cody ML, Mooney HA (1978) Convergence versus nonconvergence in Mediterranean-climate ecosystems. Annu Rev Ecol Syst 9:265-321

Cody ML, Fuentes ER, Glanz W, Hunt JH, Modenke AR (1977) Convergent evolution in the consumer organisms of Mediterranean climate ecosystems. In: Mooney HA (ed) Convergent evolution in Chile and California, Mediterranean climate ecosystems. Dowden, Hutchinson \& Ross, Stroudsberg, PA, p 144-192

Cross JN (1981) Structure of a rocky intertidal fish assemblage. PhD thesis, University of Washington, Seattle, WA

Cross JN (1982) Resource partitioning in three rocky intertidal fish assemblages. In: Cailliet GM, Simenstad CA (eds) Gutshop '81. Washington Sea Grant Press, Seattle, WA, p 142-150

Delariva RL, Agostinho AA (2001) Relationship between morphology and diets of six neotropical lorcariids. J Fish Biol 58:832-847

Engelman L (2000) Discriminant analysis. In: Anonymous (ed) Systat 10: statistics II. SPSS, Chicago, IL, p 245-296

Eschmeyer WN, Herald ES, Hammann H (1983) A field guide to Pacific coast fishes of North America. Houghton Mifflin Company, Boston, MA

Fox BJ (1995) Multivariate comparisons of the small-mammal faunas in Australian, Californian, and Chilean shrublands. In: Arroyo MTK, Zedler PH, Fox MD (eds) Ecology and biogeography of Mediterranean ecosystems in Chile, California, and Australia, Vol 108. Springer-Verlag, New York, p 363-382

Fuentes ER (1976) Ecological convergence of lizard communities in Chile and California. Ecology 57:3-17

Gatz Jr AJ (1979) Ecological morphology of freshwater stream fishes. Tulane Stud Zool 21:91-124

German DP, Horn MH (2006) Gut length and mass in herbivorous and carnivorous prickleback fishes (Teleostei:
Stichaeidae): ontogenetic, dietary, and phylogenetic effects. Mar Biol 148:1123-1134

German DP, Horn MH, Gawlicka A (2004) Digestive enzyme activities in herbivorous and carnivorous prickleback fishes (Teleostei: Stichaeidae): ontogenetic, dietary, and phylogenetic effects. Physiol Biochem Zool 77:789-804

Gibson RN, Yoshiyama RM (1999) Intertidal fish communities. In: Horn MH, Martin KLM, Chotkowski MA (eds) Intertidal fishes: life in two worlds. Academic Press, San Diego, CA, p 264-296

Gould SJ, Vrba ES (1982) Exaptation-a missing term in the science of form. Paleobiology 8:4-15

Grossman GD (1986) Food resource partitioning in a rocky intertidal fish assemblage. J Zool 1:317-355

Hart JL (1973) Pacific fishes of Canada, Vol 180. Fisheries Research Board of Canada, Ottawa

Hawkins CP, MacMahon JA (1989) Guilds: the multiple meanings of a concept. Annu Rev Entomol 34:423-451

Holmes RT, Recher HF (1986) Determinants of guild structure in forest bird communities: an intercontinental comparison. Condor 88:427-439

Horn MH (1999) Convergent evolution and community convergence: research potential using intertidal fishes. In: Horn MH, Martin KLM, Chotkowski MA (eds) Intertidal fishes: life in two worlds. Academic Press, San Diego, CA, p 356-372

Horn MH, Allen LG (1978) A distributional analysis of California coastal marine fishes. J Biogeogr 5:23-42

Horn MH, Gibson RN (1988) Intertidal fishes. Sci Am 256: $64-70$

Horn MH, Ojeda FP (1999) Herbivory. In: Horn MH, Martin KLM, Chotkowski MA (eds) Intertidal fishes: life in two worlds. Academic Press, San Diego, CA, p 197-222

Horn MH, Murray SN, Edwards TW (1982) Dietary selectivity in the field and food preferences in the laboratory for two herbivorous fishes (Cebidichthys violaceus and Xiphister mucosus) from a temperate intertidal zone. Mar Biol 67: 237-246

Horn MH, Allen LG, Lea RN (2006) Biogeography. In: Allen LG, Pondella DJ II, Horn MH (eds) The ecology of marine fishes: California and adjacent waters. University of California Press, Berkeley, CA, p 18

Hugueny B, Pouilly M (1999) Morphological correlates of diet in an assemblage of West African freshwater fishes. J Fish Biol 54:1310-1325

Jaksic FM (1981) Abuse and misuse of the term 'guild' in ecological studies. Oikos 37:397-400

Jaksic FM, Delibes M (1987) A comparative analysis of foodniche relationships and trophic guild structure in two assemblages of vertebrate predators differing in species richness: causes, correlations, and consequences. Oecologia 71:461-472

Jaksic FM, Medel RG (1990) Objective recognition of guilds: testing for statistically significant species clusters. Oecologia 82:87-92

Johnston RF (1954) The summer food of some intertidal fishes of Monterey County, California. Calif Fish Game 40:65-68

Karr JR, James FC (1975) Eco-morphological configurations and convergent evolution in species and communities. In: Cody ML, Diamond JM (eds) Ecology and evolution of communities. Belknap Press of Harvard University Press, Cambridge, MA, p 258-291

Kotrschal K (1989) Trophic ecomorphology in eastern Pacific blennioid fishes: character transformation of oral jaws and associated change of their biological roles. Environ Biol Fishes 54:199-218

Kotrschal K, Thomson DA (1986) Feeding patterns in eastern 
tropical Pacific blennioid fishes (Teleostei: Tripterygiidae, Labrisomidae, Chaenopsidae, Blenniidae). Oecologia 70: 367-378

Krebs CJ (1989) Ecological methodology. Harper \& Row Publishers, New York

Labropoulou M, Eleftheriou A (1997) The foraging ecology of two pairs of congeneric demersal fish species: importance of morphological characteristics in prey selection. J Fish Biol 50:324-350

Labropoulou M, Markakis G (1998) Morphological-dietary relationships within two assemblages of marine demersal fishes. Environ Biol Fishes 51:309-319

Lawlor LR (1980) Structure and stability in natural and randomly constructed competitive communities. Am Nat 116: 394-404

Mead GW (1970) A history of South Pacific fishes. In: Wooster WS (ed) Scientific exploration of the South Pacific. National Academy of Sciences, Washington, DC, p 236-251

Mooney HA, Kummerow J, Johnson AW, Parsons DJ and 5 others (1977) The producers - their resources and adaptive responses. In: Mooney HA (ed) Convergent evolution in Chile and California, Mediterranean-climate ecosystems. Dowden, Hutchinson \& Ross, Stroudsberg, PA, p 85-143

Motta PJ (1988) Functional morphology of the feeding apparatus of ten species of Pacific butterflyfishes (Perciformes, Chaetodontidae): an ecomorphological approach. Environ Biol Fish 22:39-67

Motta PJ, Clifton KB, Hernandez P, Eggold BT (1995a) Ecomorphological correlates in ten species of subtropical seagrass fishes: diet and microhabitat utilization. Environ Biol Fish 44:37-60

Motta PJ, Norton SF, Luczkovich JJ (1995b) Perspectives on the ecomorphology of bony fishes. Environ Biol Fish 44: 11-20

Muñoz AA, Ojeda FP (1997) Feeding guild structure of a rocky intertidal fish assemblage in central Chile. Environ Biol Fish 49:471-479

Muñoz AA, Ojeda FP (1998) Guild structure of carnivorous intertidal fishes of the Chilean coast: implications of ontogenetic dietary shifts. Oecologia 114:563-573

Muñoz AA, Ojeda FP (2000) Ontogenetic changes in the diet of the herbivorous Scartichthys viridis in a rocky intertidal zone in central Chile. J Fish Biol 56:986-998

Nelson JS (1994) Fishes of the world, 3rd edn. John Wiley \& Sons, New York

Norton SF (1991) Capture success and diet of cottid fishes: the role of predator morphology and attack kinematics. Ecology 72:1807-1819

Norton SF (1995) A functional approach to ecomorphological patterns of feeding in cottid fishes. Environ Biol Fish 44: $61-78$

Norton SF, Brainerd EL (1993) Convergence in the feeding mechanics of ecomorphologically simliar species in the Centrarchidae and Cichlidae. J Exp Biol 176:11-29

Norton SF, Cook AE (1999) Predation by fishes in the intertidal. In: Horn MH, Martin KLM, Chotkowski MA (eds) Intertidal fishes: life in two worlds. Academic Press, San Diego, CA, p 223-263

Ojeda FP, Muñoz AA (1999) Feeding selectivity of the herbivoruous fish Scartichthys viridis: effects on macroalgal community structure in a temperate rocky intertidal coastal zone. Mar Ecol Prog Ser 184:219-229

Ojeda FP, Labra FA, Muñoz AA (2000) Biogeographic patterns of Chilean littoral fishes. Rev Chil Hist Nat 73: 625-641

Orians GH, Paine RT (1983) Convergent evolution at the com- munity level. In: Futuyma DJ, Slatkin M (eds) Coevolution. Sinauer Associates, Sunderland, MA, p 431-458

Paine RT, Palmer RT (1978) Sicyases sanguineus: a unique trophic generalist from the Chilean intertidal zone. Copeia 1978:75-81

Pianka ER (1973) The structure of lizard communities. Annu Rev Ecol Syst 4:53-74

Piet GJ (1998) Ecomorphology of a size-structured tropical freshwater fish community. Environ Biol Fish 51:67-86

Platell ME, Potter IC (2001) Partitioning of food resources amongst 18 abundant benthic carnivorous fish species in marine waters on the lower west coast of Australia. J Exp Mar Biol Ecol 261:31-54

Prochazka KM, Chotkowski MA, Buth DG (1999) Biogeography of rocky intertidal fishes. In: Horn $\mathrm{MH}$, Martin KLM, Chotkowski MA (eds) Intertidal fishes: life in two worlds. Academic Press, San Diego, CA, p 332-355

Rice WR (1989) Analyzing tables of statistical tests. Evolution 43:223-225

Root RB (1967) The niche exploitation pattern of the blue-gray gnatcatcher. Ecol Monogr 37:317-350

Samuels CL, Drake JA (1997) Divergent perspectives on community convergence. Trends Ecol Evol 12:427-432

Simberloff D, Dayan T (1991) The guild concept and the structure of ecological communities. Annu Rev Ecol Syst 22: 115-143

Stepien CA (1990) Population structure, diets and biogeographic relationships of a rocky intertidal fish assemblage in central Chile: high levels of herbivory in a temperate system. Bull Mar Sci 47:598-612

Stepien CA, Dillon AK, Brooks MJ, Chase KL, Hubers AN (1997) The evolution of blennioid fishes based on an analysis of mitochondrial 12S rDNA. In: Kocher TD, Stepien CA (eds) Molecular systematics of fishes. Academic Press, San Diego, CA, p 245-270

Stoddard KM (1985) A phylogenetic analysis of some prickleback fishes (Teleostei, Stichaeidae, Xiphisterinae) from the north Pacific Ocean, with a discussion of their biogeography. MA thesis, California State University, Fullerton, $\mathrm{CA}$

Sturm EA, Horn MH (1998) Food habits, gut morphology and $\mathrm{pH}$, and assimilation efficiency of the zebraperch Hermosilla azurea, an herbivorous kyphosid fish of temperate marine waters. Mar Biol 132:512-522

Varas E, Ojeda FP (1990) Intertidal fish assemblages of the central Chilean coast: diversity, abundance and trophic patterns. Rev Biol Mar 25:59-70

Wainwright PC (1999) Ecomorphology of prey capture in fishes. In: Saksena DN (ed) Ichthyology: recent reseach advances. Science Publishers, Enfield, NH, p 453

Wells AW (1986) Aspects of ecology and life history of the woolly sculpin, Clinocottus analis, from southern California. Calif Fish Game 72:213-226

Wiens JA, Rotenberry JT (1980) Patterns of morphology and ecology in grassland and shrubsteppe bird populations. Ecol Monogr 50:287-308

Wilson JB (1999) Guilds, functional types and ecological groups. Oikos 86:507-522

Winemiller KO (1991) Ecomorphological diversification in lowland freshwater fish assemblages from five biotic regions. Ecol Monogr 61:343-365

Winemiller KO, Adite A (1997) Convergent evolution of weakly electric fishes from floodplain habitats in Africa and South America. Environ Biol Fish 49:175-186

Winemiller KO, Kelso-Winemiller LC, Brenkert AL (1995) Ecomorphological diversification and convergence in fluvial cichlid fishes. Environ Biol Fish 44:235-261 
Xie S, Cui Y, Li Z (2001) Dietary-morphological relationships of fishes in Liangzi Lake, China. J Fish Biol 58:1714-1729 Yoshiyama RM (1980) Food habits of three species of rocky intertidal sculpins (Cottidae) in central California. Copeia 1980:515-525

Yoshiyama RM, Darling JDS (1982) Grazing by the intertidal fish Anoplarchus purpurescens upon a distasteful worm. Environ Biol Fish 7:39-45

Editorial responsibility: Charles Birkeland (Contributing Editor), Honolulu, Hawaii, USA
Yoshiyama RM, Sassaman C, Lea RN (1986) Rocky intertidal fish communities of California: temporal and spatial variation. Environ Biol Fish 17:23-40

Yoshiyama RM, Sassaman C, Lea RN (1987) Species composition of rocky intertidal and subtidal fish assemblages in central and northern California, British Columbia-southeast Alaska. Bull South Calif Acad Sci 86: $134-144$

Submitted: January 30, 2005; Accepted: December 1, 2005 Proofs received from author(s): July 26, 2006 